\title{
Price hike of staple food, nutritional impact and consumption adjustment: Evidence from the 2005- 2010 rice price increase in rural Bangladesh
}

\section{Crawford School Working Paper 1702 January 2017}

\section{Syed Abul Hasan}

Crawford School of Public Policy, The Australian National University

\begin{abstract}
This paper studies the nutritional impact and the adjustment in consumption as a result of the 2005-2010 rice price increase in rural Bangladesh. We compare the net rice buyers, who suffer from a negative income effect, with the self sufficient households. Our findings indicate that rural households in Bangladesh cope well with the surge in the domestic rice price as indicated by the absence of any effect on their calorie intake and food diversity. Income plays a crucial role in dietary diversity indicating the importance of effective income support programmes at the time of food price shocks.
\end{abstract}




\section{Suggested Citation:}

Hasan, S. (2017) Price hike of staple food, nutritional impact and consumption adjustment: Evidence from the 2005-2010 rice price increase in rural Bangladesh, Crawford School working paper, January 2017. Crawford School of Public Policy, The Australian National University.

\section{Address for Correspondence:}

Name: Dr Syed Abul Hasan

Position: Research Officer

Address Crawford School of Public Policy, Australian National University

Tel: +61261258282

Email: syed.hasan@anu.edu.au

Crawford School of Public Policy

College of Asia and the Pacific

The Australian National University

Canberra ACT 0200 Australia

www.anu.edu.au

The Crawford School of Public Policy is the Australian National University's public policy school, serving and influencing Australia, Asia and the Pacific through advanced policy research, graduate and executive education, and policy impact. 


\title{
Price hike of staple food, nutritional impact and consumption adjustment: Evidence from the 2005-2010 rice price increase in rural Bangladesh
}

\author{
Syed Abul Hasan*† \\ ${ }^{\dagger}$ Crawford School of Public Policy, Australian National University
}

January 22, 2017

\begin{abstract}
This paper studies the nutritional impact and the adjustment in consumption as a result of the 2005-2010 rice price increase in rural Bangladesh. We employ a difference-in-differences framework and compare the net rice buyers, who suffer from a negative income effect, with the self sufficient households who are not affected by the change in rice price. We also compare net rice sellers, who are expected to enjoy a positive income effect, to the self sufficient households. Our findings indicate that rural households in Bangladesh cope well with the surge in the domestic rice price as indicated by no effect on their calorie intake and food diversity. We also find that all types of households similarly adjust their consumption of rice, non rice food items and non food items. Income plays a crucial role in households' dietary diversity indicating that effective income support programs at the time of large increases in the prices of staple food items are instrumental to maintain nutritional stability.
\end{abstract}

JEL Classification: D12, I32, O13, O53, Q12.

Keywords: Rice Price Increase; Difference-in-difference Estimation; Nutrition; Bangladesh.

*All correspondence to Syed Hasan, e-mail: syed.hasan@anu.edu.au. We thank Mathias Sinning, Pallab Mozumder and participants of the Australian Conference of Economists (ACE) 2016 for helpful comments and suggestions on an earlier draft. 


\section{INTRODUCTION}

Increased food prices may force households to reduce both the quantity and quality of their food consumption (Brinkman et al., 2010; Alem and Söderbom, 2012; Kumar and Quisumbing, 2013; Akter and Basher, 2014; Hasan, 2016a,b). For instance, the most vulnerable households in Afghanistan sacrificed their diet quality to maintain the intake of calorie at the time of a high food price shock in 2007-08 (D'Souza and Jolliffe, 2014). The same event also forced a large proportion of low income households in Bangladesh to reduce their consumption of non rice food items to maintain or even increase their consumption level of rice (Raihan, 2009; Sulaiman et al., 2009). Hasan (2016b) compared net rice buyers (sellers) with self sufficient households in rural Bangladesh and found that the increase in domestic rice prices between 2005 and 2010 significantly reduced (increased) the non rice food consumption of the former but did not affect their rice consumption. Such findings may have important implications; for example, Torlesse et al. (2003) observes that the proportion of underweight children is positively associated with the rice expenditure in Bangladesh, as higher expenditure on rice forced households to spend less on non rice food items and thereby reducing their diet quality.

When analysing household food consumption, it is more appropriate to rely on physical quantity (kilogram, litre, piece, unit, packet etc.) than the value of consumption as the former has several advantages in indicating the impact on households' food intake and nutrition. First, the former can capture the feedback effect of higher food prices on household consumption through home production (Becker, 1965). Second, households may find a better deal through extended shopping hours and thus potentially compensate for higher food prices (Kaplan and Menzio, 2015; Nevo and Wong, 2015). Third, the availability of different qualities of food allows households to shift quality within a food category, for example, from fine to coarse quality of rice, which can offset the effect of higher food prices (Griffith et al., 2016). Finally, physical quantity permits avoiding the complexity arising from the uneven price increase in different food items, as we observe between 2005 and 2010 in Bangladesh.

Instead of advantages of analysing physical quantity, the aggregation problem arising from the consumption of different types of food items with diverse units of measurement complicates its use. For example, rice is consumed in different forms in Bangladesh including puffed rice, beaten 
rice and plain rice, all with different nutritional contents. Thus an analysis needs to address such aggregation problem to be useful in examining the impact of higher food prices on household consumption. Using calorie content of each food item has the potential to solve these problems. Some studies like D'Souza and Jolliffe $(2012,2014)$ focus on the impact of higher food prices on the calorie intake of different expenditure groups. Since calorie intake is not sufficient to indicate the impact, these studies also examine the impact on household dietary diversity. While studies like Ivanic and Martin (2008) and Hasan (2017) indicate a negative effect of increased staple food price on poverty, we know very little about the impact of the 2005-2010 rice price increase in Bangladesh on the calorie intake and dietary diversity of potentially the most affected group of net rice buyers. ${ }^{1}$

Against this background, this paper uses the calorie content of consumed food items to study the effect of 2005-2010 rice price increase on the food consumption of net rice buyers and net rice sellers in rural Bangladesh. Dietary diversity is also examined to complement the study on calorie intake. We further looked into the pattern of adjustments in consumption, separately for rice, non rice food items and non food items. In doing so, we use the 2005 and 2010 waves of the Bangladesh household Income and Expenditure (HIES) survey data. The nationally representative survey allows us to exploit the quasi experimental setting of the rice price increase between 2005 and 2010 and employ a difference-in-difference (DD) framework with autarkic (self sufficient) households as the control group and buyer households as the treatment group. Since we expect an opposite effect on sellers, we repeated our analysis on them by employing the same control group.

Our results demonstrate no significant effect of a higher rice price on the calorie intake and dietary diversity of net rice buyers and sellers, indicating that rural households in Bangladesh cope well with the rice price shock. We also find that buyers, sellers and autarkic households change their consumption of rice, non rice food items and non food items in a similar fashion. Depending on the context, our findings may assist in improving the public policy decisions to support the low income households during a food price shock.

This paper contributes to the literature on the impact of higher food prices on household consumption in several ways. First, we show the impact of 2005-2010 rice prices increase on the calorie intake of rural households in Bangladesh. Second, we analyse the impact of the price increase on their dietary diversity. The findings in this study, together with the results of Hasan (2016b), imply that using the value of food consumption in an analysis may provide a different 
conclusion compared to those arising from using calorie intake and dietary diversity. Third, we indicate households' adjustment pattern for the consumption of rice, non rice food items and non food items as they experience an increase in rice price in Bangladesh between 2005 and 2010. Our study can particularly be useful for developing countries that experience a surge in the price of staple food items.

The remainder of this article is organised as follows. Section 2 briefly describes the data. Section 3 presents the methodology, the empirical strategy and the identifying assumptions. Results from our analysis are presented at Section 4 . Section 5 concludes.

\section{DATA}

We employ data from the 2005 and 2010 round of Bangladesh Household Income and Expenditure Survey (HIES). The HIES is a repeated cross sectional survey, conducted every 5 years to generate nationally representative socioeconomic information at the household level. Households in the survey are selected in a two stage stratified random sampling framework with 10,080 households in 2005 and 12,240 households in 2010 (BBS, 2007, 2012). Since this analysis is only conducted on rural households, we exclude 8,080 urban households from the sample. ${ }^{2}$ We further drop 1,184 observations with missing consumption information, 395 households with nonpositive/missing income and 989 observations with missing house rent from our analysis. Thus our analysis sample includes 4,978 observations in 2005 and 6,744 observations in 2010 .

Since the definition of buyer, autarkic and seller households are not explicit in our data, we use a methodology similar to the one in Hasan (2016b) and compare a household's daily consumption with its capacity to produce rice, in which the latter depends on the average rice yield and the size of agricultural land owned by the household. ${ }^{3}$ Buyers (sellers) are defined to have a lower (higher) productive capacity than required consumption while the two are equal for autarkic households. In specific, households are classified as buyers if they own less than 0.17 acre of cultivable land which is just inadequate to support their average consumption of $428 \mathrm{~g}$ of rice (per capita per day). On the other hand, households with more than 0.50 acre of cultivable land are characterised as sellers. Those in between these two cutoffs are categorised as autarkic households. ${ }^{4}$ Our definition yields 
a total of 8,916 buyers, 950 sellers and 1,856 autarkic households. Note that, while analysing the impact on buyers, sellers are excluded from the analysis and vice-versa.

The primary variable of interest in our analysis is the total calorie intake (per capita per day) which is constructed using the calorie content of each food items, provided in our data. To look into the impact on the consumption of rice and non rice food items we also consider calorie intake from rice and non rice food items in two separate analyses, while quantity of rice consumption is analysed as a robustness check.

Table 1 presents summary statistics of the dependent variables by types of households. Calorie intake related variables at Panel A in the table shows that the total calorie intake for all types of households remain largely similar over time. However, we observe an over time increase in the calorie intake from non rice food items and a decrease in the calorie intake from rice. Interestingly the intake of calorie, both from rice and non rice food items, increases with household's capacity to produce rice relative to its consumption requirement (that is, as household type moves from buyer to autarkic to seller).

\section{[Table 1]}

While calorie intake is a key indicator of household food consumption, it is not sufficient to indicate the diversity in household diet that is required for good health. In order to identify the impact of higher rice prices on dietary diversity, we used two simple indicators, Household Dietary Diversity Score (HDDS) and Food Consumption Score (FCS). Both HDDS and FCS are widely used in empirical work on dietary diversity (for example, Steyn et al., 2006; Kennedy et al., 2007; Jones et al., 2013, 2014).

The HDDS counts the number of nutritional food groups consumed by a household in a reference period (Swindale and Bilinsky, 2006). This usually is a better indicator than the count of different food items, which may all be cereals. The following 12 food groups is used to calculate the HDDS: i. cereals, ii. roots and tubers, iii. pulses and nuts, iv. vegetables, v. fruit, vi. meat, vii. eggs, viii. fish and seafood, ix. milk and dairy products, x. oil and fats, xi. sugar and xii. miscellaneous (for example, condiments). Thus the maximum HDDS score for a household is 12 . The recommended recall period for collecting data in calculating HDDS is 24 hours, although it is common to employ modified versions of the index (for example, Jones et al., 2014). Our data rely on the diary method 
in collecting consumption data, in which daily data on food and beverage consumption are recorded (BBS, 2012). Thus employed HDDS in our analysis relies on the recommended recall period.

The FCS, on the other hand, relies on food frequency using 7 day recall data (World Food Programme, 2008). The following 8 food groups [weights within brackets] are considered to calculate the FCS: i. staple grains and tubers [2], ii. pulses [3], iii. vegetables [1], iv. fruits [1], v. meat and fish [4], vi. dairy products [4], vii. sugar [0.5] and viii. oil and fat [0.5]. The assigned weights for all food groups, which are based on the energy, protein and micronutrient densities of each food group, are then multiplied with frequencies and added up to get the FCS value for each household.

As a robustness check to the analysis with HDDS and FCS, we additionally examined the impact on the number of food groups and number of food items in household consumption. ${ }^{5}$ HIES provides item wise food consumption data. The total number of food items in our data is 156 . The number of food group is obtained by aggregating similar food items. The 17 food categories considered in our analysis are i. rice, ii. puffed and beaten rice, iii. flour, iv. cakes and cookies, v. pulses, vi. fish, vii. eggs, viii. meat and poultry, ix. vegetables, x. diary, xi. sweets, xii. oil and fat, xiii. fruits, xiv. drinks, xv. sugar and ice cream, xvi. sauces and food additives, and xvii. food taken outside home.

The Panel B in Table 1 focuses on dietary diversity related dependent variables. Similar to the case with calorie intake, dietary diversity increases with household's relative capacity to produce rice as indicated by all the variables representing dietary diversity. Consistent with the increase in non rice food consumption, as seen in Panel A, we observe an increase in the dietary diversity for all types of households over time.

The summary statistics of relevant demographic and socioeconomic variables are presented in Table 2. In the table, we observe a reduction in household size over time. With the increase in rice production capacity, we observe an increase in household education as well as the age of household heads while the proportion of female headed households remains similar. Household type also appears to be correlated with per capita income and consumption. For both periods, the more a household's capacity to produce rice, the higher its income and consumption.

\section{[Table 2]}




\section{EMPIRICAL STRATEGY}

The rice price increase between 2005 and 2010 was caused by some exogenous events. ${ }^{6}$ This allows us to use a difference-in-difference (DD) framework as follows

$$
Y_{i}=\alpha+\beta \text { Treatment }_{i}+\gamma \text { Post }_{i}+\delta \text { Treatment }_{i} \times \text { Post }_{i}+X_{i} \psi+\phi_{d i}+u_{i}
$$

where, for each individual $i, Y$ denotes the calorie intake (and other dependent variables for subsequent analyses), Post is an indicator of price increase which takes the value of 1 for the year 2010 (reference year is 2005), Treatment is an indicator of treatment group which takes the value of 1 for net rice buyers (control group consists of autarkic households) and $u$ is the error term. The vector $X$ includes income per capita, agricultural asset value, household head's age, proportion of male and female in different demographic groups and dummies for educational categories of household head/spouse, female head and the season of data collection. The model additionally includes district fixed effects $\left(\phi_{d}\right)$ to net out time invariant factors (such as the climate and irrigation facility in a district). The DD estimator $\delta$ measures the effect of the higher rice price in 2010 on the calorie intake of net rice buyers, compared to the autarkic households.

The identifying assumption in our analysis is that the difference in calorie consumption between treatment (buyer) and control (autarkic) groups would have remained similar in the absence of any change in rice price. We cannot test our identifying assumption directly but in the absence of any evidence for change in food consumption pattern between 2005 and 2010 in rural Bangladesh, we assume that the underlying trend in the dependent variable remains the same for both the treatment

and the control group. As a result, the OLS estimate of $\delta$ in equation (1) can be considered as the average treatment effect (ATE).

A joint determination of income and the dependent variable can make the former endogenous in our model. This is, however, unlikely in our case with a large proportion of low income households. For them we may consider a two stage budgetary framework in which households first decide total consumption and then conditional on consumption, decide consumption of (and consequently the calorie intake from) each types of food items. We thus assume income exogenous in our models. 


\section{Results And Discussion}

We start our analysis with total calorie intake (per capita per day) as the dependent variable. Column 1 of Table 3 presents the OLS estimates of model (1) parameters. ${ }^{7}$ They indicate no change in the calorie intake of the reference households over time. Buyers have a significantly lower intake of calorie compared to the autarkic households. However, as indicated by the DD estimate, they have not significantly modified their calorie intake after the rice price increase. Among other variables, age and sex of household head affect the calorie intake of households, indicating that younger and female headed households are better in maintaining calorie consumption. Income and household education does not seem to explain much of the calorie intake. This can be due to their strong correlation with other variables in the model that captures the socioeconomic status (SES) of households, like agricultural asset value which significantly affects the calorie intake of households. It is also likely that households may need to feed hired labors and their numbers may increase with the value of agricultural asset they own.

\section{[Table 3]}

Next, we repeat the same analysis but separately for the calorie intake from non rice food items and from rice. The estimates in Column 2 of Table 3 indicate an increase over time in non rice consumption while estimates in column 3 indicates a reduction over time in rice consumption. Again, buyers have a lower consumption of both rice and non rice food items. However, in no cases, buyers exhibit any differences in the adjustment of consumption indicated by insignificant DD estimates. Among other important explanatory variables, income per capita significantly explains non rice consumption but not the consumption of rice. Interestingly, education of both household heads and their spouses positively affect non rice food consumption while the opposite is true for the consumption of rice. A possible explanation is the association of education with knowledge about nutrition, which can play an important role in households' dietary diversity (Fitzsimons et al., 2016). Again, agricultural asset value significantly affects the calorie intake of households from both sources. The insignificant effect on rice consumption is also confirmed by an analysis with the physical quantity of consumed rice (in kilogram), presented in Column 4. 
A particular concern about our analysis can be the definition of buyer, autrarkic and seller households. In particular, the required size of owned cultivable land employed to define buyer, autarkic and seller households can be claimed to be arbitrary. In order to examine the effect of the subjectivity of the definitions, we repeat the analysis in Table 3 with gradually moving the requirement cutoffs for the buyer and the autarkic households. The plot of the estimates in Figure 1 demonstrates that the DD estimates are insignificant in all cases, indicating that our results are robust to a wide range of cutoffs used to define buyer and autarkic households.

\section{[Figure 1]}

Another concern in the DD analysis is the artificially high significance level of the DD estimates. This can be particularly true when the errors are serially correlated, resulting the DD standard errors to understate the standard deviation (Bertrand et al., 2004). Even though the concern is not valid in our case as the DD estimates are not significant, we confirm the actual significance level for our estimates. For that, we randomly assign the treatment status to our sample households and then simulate the level of significance of the DD estimates. Results from such tests, presented in Table 4, indicate that the actual significance level of the DD estimates correspond to the standard normal distribution.

\section{[Table 4]}

Our results are robust to a number of modifications in our model. For example, using per capita calorie intake may provide different results if the demographic characteristics are different between the treatment and the control group. In such case, using equivalised calorie intake, adjusted for calorie need for different demographic groups, may provide different results. Using household level variables with demographic controls in the model may also be useful. However, our analysis with both of these approaches provide similar results. Another issue is that income, which enters linearly in our model, may have a nonlinear relation with food consumption (Hasan, 2016a). Thus our model results, including the DD estimates can be biased. Again, DD estimates from semiparametric models, in which income enters nonparametrically (allowing for nonlinear relationship) but other variables enter linearly, also indicate no impact on the buyers. While employing linear models can be an issue, using log linear models also provide similar results. ${ }^{8}$ 
Next we investigate the impact on the dietary diversity of buyers. The Household Dietary Diversity Score presented in Column 1 of Table 5 shows that buyers food basket is less diversified than the autarkic households. However, while the dietary diversity increases over time, it changes similarly for both buyers and autarkic households. As expected, income positively affects dietary diversity. The age of household head also increases diversity in diet while female head affects it negatively. As we find earlier, education seems to positively affect the dietary diversity of households, possibly through their better understanding of nutritional requirements. Agricultural asset value also plays a significant role in improving the dietary diversity of rural households which, as we discussed earlier, can be due to its high correlation with income.

\section{[Table 5]}

When we consider the Food Consumption Score as another indicator of dietary diversity, although we do not observe any change over time, we arrive at a similar conclusion (Column 2 of Table 3). Similar results are also observed when we repeat the analysis either with the number of food items consumed (Column 3) or with the number of food groups consumed (Column 4) as the dependent variable. Thus our results in Table 5 indicate no effect of higher rice price on the dietary diversity of buyers. An important feature of the results presented in the table is that all explanatory variables, except the time dummies and the DD estimates, are highly significant in all models.

It is likely that buyers who are hard hit by the rice price increase may shift from high to low value food categories, for example, from protein to pulses. In case the hypothesis is true, we would expect a reduction in the calorie intake from high value categories and the opposite for low value categories for buyers. To examine this hypothesis, we model separately for the calorie intake from grains, non rice grains, pulses, protein, fruits and other items and compare buyers and autarkic households. Results in Table 6 indicate a similar change in the consumption pattern of all these categories for both types of households and thus provide no evidence of shifting from high to low value food categories in adjusting to the price shock.

\section{[Table 6]}


It is also possible that buyers may shift to cheaper items within each category to cope with high rice prices. We investigate the hypothesis by comparing the consumption pattern of buyers and autarkic households specifically for high and low value pulses and, in a separate analysis, for fishes. ${ }^{9}$ Our results in Column 1 of Table 7 indicate that while the calorie intake from the high value pulses are lower for the former group, there is no significant effect of the price shock on its consumption. We also find a similar consumption pattern for low value pulses (Column 2 of Table 7). No effect is observed on the consumption of high value fishes, but we find a significant reduction in the consumption of low value fishes. However, fish prices may suffer from strong seasonal effects. For instance, Hilsa is very expensive during off season but can be inexpensive during the harvesting season. Therefore, our results may not necessarily indicate a shift to low quality items.

\section{[Table 7]}

Thus our overall findings provide no evidence of any impact on the calorie intake and food diversity of the buyers in rural Bangladesh indicating that they adjust well with the increase in domestic rice prices. This is particularly interesting as Hasan (2016b) observes a reduction in the value of consumption of non rice food items for buyers and the opposite for the sellers. An initial examination into our data reveals that both types of households similarly increase their (inflation adjusted) consumption value of rice (27-28\%) and non rice food items (55-56\%). However, the increase is much larger at higher quintiles of the dependent variables. Thus a reason for the findings in Hasan (2016b) can be the heterogeneity in non rice food consumption.

To examine the possibility, we repeat the analysis in Hasan (2016b) and use a specification similar to equation (1) with values of rice consumption, non rice food consumption and non food consumption as the dependent variable. However, to avoid the influence of large values, now we employ the dependent variables in logarithms. As Figure 2 indicates, the logarithmic transformation of the dependent variables allows them to follow a normal distribution more closely. The DD estimate in such case would indicate the percentages differences in (the value of) consumption between buyers and autarkic households. An additional advantage of such models is that they can indicate elasticities that are particularly useful for providing policy guidelines.

\section{[Figure 2]}


Results in Table 8 indicate the impact on the value of consumption of rice, non rice food items and non food items. Column 1 result shows a $75 \%$ increase in the value of rice consumption over time for the autarkic (reference) households. It also indicates that buyers consume $6 \%$ less rice in 2005 compared to the autarkic households. However, we observe a low and insignificant DD estimate, indicating that buyer and autarkic households change their rice consumption similarly as its price increases. Specifically, it indicates that both households increase their rice consumption by $75 \%$ between the two survey periods. Column 2 result indicates a $93 \%$ increase over time in the value of non rice food consumption for the autarkic (reference) households. Similar to the case of rice, buyers also consume $17 \%$ less non rice food items compared to the autarkic households. We again observe a low and insignificant DD estimate indicating that as rice prices increase buyer and autarkic households change their non rice food consumption in the same way. We also observe a similar pattern for the consumption of non food items for these two types of households. Thus our results indicate that buyer and autarkic households in rural Bangladesh changes the consumption of rice, non rice food items and non food items in a similar fashion.

\section{[Table 8]}

To confirm our findings for sellers, we repeat the previous analyses on sellers and find similar results. ${ }^{10}$ Thus our analysis with sellers, together with the findings in Hasan (2016b), indicates that both sellers and autarkic households similarly change their consumption of rice, non rice food items and non food items. Combining the results for buyers and sellers indicate that rural households in Bangladesh exhibit a similar adjustment pattern in consumption of rice, non rice food items and non food items in the face of a surge in rice price. Our findings are consistent with some studies that indicate no impact on households' food consumption pattern as they face a price or income shock (for example, Nevo and Wong, 2015; Griffith et al., 2016). This can be due to an increased home production or by finding a better deal through extended shopping hours but less likely through the shift in food quality, as our analysis reveals. Nevertheless, our findings are opposite to some studies that find that the price increase results in a less diversified food basket than before (for example, Torlesse et al., 2003; West and Mehra, 2010).

An important variable in our analysis which deserves attention is income. Controlling for income can take care of the income effect that buyers/sellers experience and thus can result in 
insignificant DD estimates in our models. Although income is not always significant in our models, it is significantly and positively associated with the consumption of non rice food items (Column 2 of Table 3 and Column 2 of Table 8) and the dietary diversity of households (Table 5). An immediate policy prescription from such findings is that income support policies can play a crucial role in enhancing the dietary diversity of low income households. Thus it is important to recognise that income support programs can be an essential part of any intervention designed to protect the low income people from higher food price shocks.

This study may have important implication for developing countries like Bangladesh where governments aim to support the low income households at the time of a food price shock (MoFDM,

2006; Planning Commission, 2015). Our investigation indicates that, while a staple food price increase can affect the value of consumption of other types of food items, it may not have any effect on the intake of the food items and thus the nutritional status of households. Income plays a crucial role in ensuring the dietary diversity of rural households. As a result, in the face of a food price shock, an income support program can protect the low income households from any nutritional deficiencies.

\section{Conclusion}

We investigate the impact on and adjustment of food consumption of the 2005-2010 rice price increase on net buyers and net sellers of rice in rural Bangladesh. Employing the 2005 and 2010 waves of household expenditure data in a quasi experimental setting, we find no significant effect of higher rice prices on the food consumption pattern of net rice buyers and net rice sellers compared to the self sufficient households. We also find that it has no impact on households' dietary diversity. We find no evidence that buyers (sellers) have shifted to low (high) value groups or items. Rather, to cope with higher rice prices, they adjust their consumption in a similar proportion to the autarkic households.

By examining the calorie intake of consumed items, this analysis overcomes the problem of aggregation of different food items as well as uneven price increases for different food categories and provides a better understanding of the impact on household consumption. An important implication of our analysis is that the governments in the developing countries, which aim to protect 
the low income households from food price shocks, need not to worry too much about the nutritional consequences of higher staple food price shock as long as they provide income support to the low income households. Income plays an important role in ensuring food diversity and any support from the government to the low income people can help in avoiding nutritional consequences.

Empirical studies find safety net programs, irrespective of paying cash or food, reducing food insecurity (Schmidt et al., 2017). However, such programs are often difficult to implement in developing countries as governments usually lack the capacity to effectively deliver the support to targeted beneficiaries. Emerging technologies such as smartcards, that biometrically authenticate beneficiaries, can be useful in connecting them to secured payments infrastructure and help the government to reach the beneficiaries. Such method results in an effective delivery mechanism that is faster, more predictable and less corrupt (Muralidharan et al., 2016). Bangladesh has established a universal National ID system for its citizen and eager to boost its use (Planning Commission, 2015). As a result, it can be appropriate for the country to use the system to make any cash transfer to the low income households. Other developing countries may also significantly benefit from connecting biometrically authenticate beneficiaries to secured payments mechanism.

Nonetheless, it is likely that the fiscal burden would allow the Government to implement the program only for a short period. In such case, a more appropriate and sustainable medium to long run solution would require increasing investment in rice research and development to raise the farm productivity which may enhance the capacity to absorb the shock due any increase in rice price (Hasan, 2017). 


\section{Tables ANd Figures}

TABLE 1: Summary statistics of dependent variables by household type (weighted)

PANEL A: Calorie intake related variables

\begin{tabular}{|c|c|c|c|c|c|c|}
\hline & \multicolumn{3}{|c|}{2005} & \multicolumn{3}{|c|}{2010} \\
\hline & Buyer & Autarkic & Seller & Buyer & Autarkic & Seller \\
\hline \multicolumn{7}{|c|}{ Total calorie intake (Kcal. per capita per day) } \\
\hline Mean & 2,229 & 2,537 & 2,850 & 2,328 & 2,606 & 3,055 \\
\hline SD & 601 & 754 & 1,028 & 718 & 751 & 1,171 \\
\hline Min & 353 & 749 & 992 & 546 & 861 & 973 \\
\hline Max & 8,504 & 7,243 & 8,998 & 12,881 & 7,495 & 12,408 \\
\hline \multicolumn{7}{|c|}{ Calorie intake from non-rice (Kcal. per capita per day) } \\
\hline Mean & 620 & 775 & 956 & 793 & 959 & 1,215 \\
\hline $\mathrm{SD}$ & 318 & 410 & 498 & 432 & 489 & 668 \\
\hline Min & 129 & 215 & 252 & 101 & 151 & 297 \\
\hline $\operatorname{Max}$ & 3,314 & 3,627 & 4,766 & 6,282 & 5,476 & 6,131 \\
\hline \multicolumn{7}{|c|}{ Calorie intake from rice (Kcal. per capita per day) } \\
\hline Mean & 1,610 & 1,762 & 1,894 & 1,535 & 1,647 & 1,840 \\
\hline $\mathrm{SD}$ & 474 & 536 & 705 & 507 & 496 & 716 \\
\hline Min & 132 & 494 & 288 & 309 & 371 & 433 \\
\hline Max & 5,190 & 5,190 & 5,221 & 8,650 & 4,943 & 7,291 \\
\hline \multicolumn{7}{|c|}{ Rice consumption per capita (Kg per month) } \\
\hline Mean & 14.19 & 15.54 & 16.70 & 13.53 & 14.52 & 16.22 \\
\hline $\mathrm{SD}$ & 4.18 & 4.73 & 6.21 & 4.46 & 4.37 & 6.31 \\
\hline Min & 1.17 & 4.36 & 2.54 & 2.72 & 3.27 & 3.81 \\
\hline Max & 45.75 & 45.75 & 46.02 & 76.25 & 43.57 & 64.27 \\
\hline $\mathrm{N}$ & 3,696 & 843 & 439 & 5,220 & 1,013 & 511 \\
\hline
\end{tabular}

PANEL B: Dietary diversity related variables

\begin{tabular}{|c|c|c|c|c|c|c|}
\hline & \multicolumn{3}{|c|}{2005} & \multicolumn{3}{|c|}{2010} \\
\hline & Buyer & Autarkic & Seller & Buyer & Autarkic & Seller \\
\hline \multicolumn{7}{|c|}{ Household dietary diversity score (HDDS) } \\
\hline Mean & 9.89 & 10.33 & 10.60 & 9.96 & 10.49 & 10.69 \\
\hline $\mathrm{SD}$ & 1.60 & 1.43 & 1.40 & 1.58 & 1.40 & 1.33 \\
\hline Min & 5.00 & 5.00 & 6.00 & 5.00 & 6.00 & 5.00 \\
\hline Max & 12.00 & 12.00 & 12.00 & 12.00 & 12.00 & 12.00 \\
\hline \multicolumn{7}{|c|}{ Food consumpion score (FCS) } \\
\hline Mean & 67.95 & 73.66 & 76.96 & 68.11 & 73.87 & 77.37 \\
\hline $\mathrm{SD}$ & 15.13 & 16.35 & 16.33 & 14.94 & 15.93 & 16.75 \\
\hline Min & 44.00 & 46.50 & 46.00 & 45.50 & 47.00 & 48.50 \\
\hline Max & 112.00 & 112.00 & 112.00 & 112.00 & 112.00 & 112.00 \\
\hline \multicolumn{7}{|l|}{$\underline{\text { Items }}$} \\
\hline Mean & 33.68 & 36.92 & 38.38 & 34.38 & 37.53 & 39.29 \\
\hline $\mathrm{SD}$ & 8.78 & 8.37 & 8.26 & 9.05 & 8.64 & 8.79 \\
\hline Min & 10.00 & 17.00 & 16.00 & 11.00 & 15.00 & 16.00 \\
\hline Max & 62.00 & 66.00 & 69.00 & 79.00 & 80.00 & 71.00 \\
\hline \multicolumn{7}{|c|}{ Food types } \\
\hline Mean & 10.19 & 11.14 & 11.70 & 10.70 & 11.67 & 12.06 \\
\hline $\mathrm{SD}$ & 2.80 & 2.66 & 2.50 & 2.91 & 2.74 & 2.72 \\
\hline Min & 3.00 & 4.00 & 5.00 & 3.00 & 4.00 & 3.00 \\
\hline Max & 17.00 & 17.00 & 17.00 & 17.00 & 17.00 & 17.00 \\
\hline $\mathrm{N}$ & 3,696 & 843 & 439 & 5,220 & 1,013 & 511 \\
\hline
\end{tabular}


TABLE 2: Summary statistics of independent variables by household type (weighted)

\begin{tabular}{|c|c|c|c|c|c|c|}
\hline & \multicolumn{3}{|c|}{2005} & \multicolumn{3}{|c|}{2010} \\
\hline & Buyer & Autarkic & Seller & Buyer & Autarkic & Seller \\
\hline \multicolumn{7}{|l|}{ Demographics } \\
\hline$\overline{\text { Family size }}$ & $\begin{array}{c}4.92 \\
(2.03)\end{array}$ & $\begin{array}{l}5.20 \\
(2.24)\end{array}$ & $\begin{array}{c}4.82 \\
(2.43)\end{array}$ & $\begin{array}{c}4.67 \\
(1.89)\end{array}$ & $\begin{array}{c}4.66 \\
(1.94)\end{array}$ & $\begin{array}{c}4.28 \\
(2.00)\end{array}$ \\
\hline Adult member & $\begin{array}{c}2.53 \\
(1.10)\end{array}$ & $\begin{array}{c}2.93 \\
(1.37)\end{array}$ & $\begin{array}{c}3.07 \\
(1.60)\end{array}$ & $\begin{array}{c}2.52 \\
(1.10)\end{array}$ & $\begin{array}{c}2.82 \\
(1.31)\end{array}$ & $\begin{array}{c}2.85 \\
(1.27)\end{array}$ \\
\hline Child member & $\begin{array}{c}2.40 \\
(1.52)\end{array}$ & $\begin{array}{c}2.28 \\
(1.53)\end{array}$ & $\begin{array}{c}1.75 \\
(1.41)\end{array}$ & $\begin{array}{c}2.14 \\
(1.42)\end{array}$ & $\begin{array}{c}1.84 \\
(1.35)\end{array}$ & $\begin{array}{c}1.43 \\
(1.31)\end{array}$ \\
\hline Age of household head & $\begin{array}{c}44.53 \\
(13.25)\end{array}$ & $\begin{array}{c}49.28 \\
(13.95)\end{array}$ & $\begin{array}{l}51.92 \\
(14.65)\end{array}$ & $\begin{array}{c}45.19 \\
(13.82)\end{array}$ & $\begin{array}{c}49.81 \\
(14.30)\end{array}$ & $\begin{array}{c}53.61 \\
(14.84)\end{array}$ \\
\hline Female head & $\begin{array}{c}0.10 \\
(0.31)\end{array}$ & $\begin{array}{c}0.09 \\
(0.29)\end{array}$ & $\begin{array}{c}0.10 \\
(0.29)\end{array}$ & $\begin{array}{c}0.15 \\
(0.36)\end{array}$ & $\begin{array}{c}0.15 \\
(0.36)\end{array}$ & $\begin{array}{c}0.11 \\
(0.32)\end{array}$ \\
\hline \multicolumn{7}{|l|}{ Education } \\
\hline $\begin{array}{l}\text { Household head with no } \\
\text { education }\end{array}$ & $\begin{array}{c}0.68 \\
(0.47)\end{array}$ & $\begin{array}{c}0.47 \\
(0.50)\end{array}$ & $\begin{array}{c}0.31 \\
(0.46)\end{array}$ & $\begin{array}{c}0.66 \\
(0.47)\end{array}$ & $\begin{array}{c}0.46 \\
(0.50)\end{array}$ & $\begin{array}{c}0.38 \\
(0.49)\end{array}$ \\
\hline $\begin{array}{l}\text { Household head with } \\
\text { primary education }\end{array}$ & $\begin{array}{c}0.15 \\
(0.35)\end{array}$ & $\begin{array}{c}0.16 \\
(0.37)\end{array}$ & $\begin{array}{c}0.15 \\
(0.36)\end{array}$ & $\begin{array}{c}0.15 \\
(0.36)\end{array}$ & $\begin{array}{c}0.16 \\
(0.37)\end{array}$ & $\begin{array}{c}0.14 \\
(0.34)\end{array}$ \\
\hline $\begin{array}{l}\text { Household head with } \\
\text { secondary education }\end{array}$ & $\begin{array}{c}0.15 \\
(0.36)\end{array}$ & $\begin{array}{c}0.28 \\
(0.45)\end{array}$ & $\begin{array}{c}0.37 \\
(0.48)\end{array}$ & $\begin{array}{c}0.16 \\
(0.36)\end{array}$ & $\begin{array}{c}0.28 \\
(0.45)\end{array}$ & $\begin{array}{c}0.32 \\
(0.47)\end{array}$ \\
\hline Household head with & 0.02 & 0.08 & 0.16 & 0.03 & 0.08 & 0.14 \\
\hline higher sec. education & $(0.14)$ & $(0.27)$ & $(0.36)$ & $(0.16)$ & $(0.28)$ & $(0.35)$ \\
\hline $\begin{array}{l}\text { Spouse with no } \\
\text { education }\end{array}$ & $\begin{array}{c}0.72 \\
(0.45)\end{array}$ & $\begin{array}{c}0.60 \\
(0.49)\end{array}$ & $\begin{array}{c}0.44 \\
(0.50)\end{array}$ & $\begin{array}{c}0.66 \\
(0.47)\end{array}$ & $\begin{array}{c}0.52 \\
(0.50)\end{array}$ & $\begin{array}{c}0.50 \\
(0.50)\end{array}$ \\
\hline $\begin{array}{l}\text { Spouse with primary } \\
\text { education }\end{array}$ & $\begin{array}{c}0.14 \\
(0.35)\end{array}$ & $\begin{array}{c}0.16 \\
(0.37)\end{array}$ & $\begin{array}{c}0.20 \\
(0.40)\end{array}$ & $\begin{array}{c}0.16 \\
(0.37)\end{array}$ & $\begin{array}{c}0.18 \\
(0.38)\end{array}$ & $\begin{array}{c}0.15 \\
(0.36)\end{array}$ \\
\hline $\begin{array}{l}\text { Spouse with secondary } \\
\text { education }\end{array}$ & $\begin{array}{c}0.13 \\
(0.33)\end{array}$ & $\begin{array}{c}0.22 \\
(0.42)\end{array}$ & $\begin{array}{c}0.31 \\
(0.46)\end{array}$ & $\begin{array}{c}0.17 \\
(0.38)\end{array}$ & $\begin{array}{c}0.28 \\
(0.45)\end{array}$ & $\begin{array}{c}0.29 \\
(0.45)\end{array}$ \\
\hline $\begin{array}{l}\text { Spouse with higher } \\
\text { secondary education }\end{array}$ & $\begin{array}{c}0.01 \\
(0.09)\end{array}$ & $\begin{array}{c}0.02 \\
(0.13)\end{array}$ & $\begin{array}{c}0.04 \\
(0.20)\end{array}$ & $\begin{array}{c}0.01 \\
(0.08)\end{array}$ & $\begin{array}{c}0.03 \\
(0.16)\end{array}$ & $\begin{array}{c}0.06 \\
(0.24)\end{array}$ \\
\hline \multicolumn{7}{|l|}{ Finances } \\
\hline Income per capita (Tk.) & $\begin{array}{c}975 \\
(888)\end{array}$ & $\begin{array}{l}1,450 \\
(2391)\end{array}$ & $\begin{array}{c}2,597 \\
(9,620)\end{array}$ & $\begin{array}{c}2,065 \\
(3,233)\end{array}$ & $\begin{array}{c}3,621 \\
(11682)\end{array}$ & $\begin{array}{c}4,444 \\
(10160)\end{array}$ \\
\hline $\begin{array}{l}\text { Consumption per capita } \\
\text { (Tk.) }\end{array}$ & $\begin{array}{c}979 \\
(767)\end{array}$ & $\begin{array}{l}1,308 \\
(887)\end{array}$ & $\begin{array}{c}1,825 \\
(1,820)\end{array}$ & $\begin{array}{c}1,974 \\
(1,391)\end{array}$ & $\begin{array}{c}2,592 \\
(1,365)\end{array}$ & $\begin{array}{c}3,677 \\
(2,521)\end{array}$ \\
\hline \multicolumn{7}{|l|}{ Landholding } \\
\hline $\begin{array}{l}\text { Owned cultivable land } \\
\text { per capita (acre) }\end{array}$ & $\begin{array}{c}0.03 \\
(0.05)\end{array}$ & $\begin{array}{c}0.31 \\
(0.11)\end{array}$ & $\begin{array}{c}1.05 \\
(0.88)\end{array}$ & $\begin{array}{c}0.03 \\
(0.05)\end{array}$ & $\begin{array}{c}0.31 \\
(0.11)\end{array}$ & $\begin{array}{c}1.09 \\
(0.86)\end{array}$ \\
\hline \multicolumn{7}{|l|}{ Other } \\
\hline$\overline{\text { Lean Season }}$ & $\begin{array}{c}0.18 \\
(0.38)\end{array}$ & $\begin{array}{c}0.15 \\
(0.36)\end{array}$ & $\begin{array}{c}0.15 \\
(0.35)\end{array}$ & $\begin{array}{c}0.15 \\
(0.36)\end{array}$ & $\begin{array}{c}0.16 \\
(0.37)\end{array}$ & $\begin{array}{l}0.15 \\
(0.36)\end{array}$ \\
\hline $\begin{array}{l}\text { Agricultural asset per } \\
\text { capita }(2010 \text { Tk.1,000) }\end{array}$ & $\begin{array}{c}199 \\
(1,099)\end{array}$ & $\begin{array}{c}1,236 \\
(6,233)\end{array}$ & $\begin{array}{c}2,299 \\
(5,530)\end{array}$ & $\begin{array}{c}625 \\
(8,376)\end{array}$ & $\begin{array}{c}2,177 \\
(10,644)\end{array}$ & $\begin{array}{c}6,089 \\
(17,811)\end{array}$ \\
\hline $\mathrm{N}$ & 3,696 & 843 & 439 & 5,220 & 1,013 & 511 \\
\hline
\end{tabular}

Note: Standard deviations in parentheses. 
TABLE 3: Effect of the 2005-2010 rice price increase on the Buyers' consumption

\begin{tabular}{|c|c|c|c|c|}
\hline & \multicolumn{3}{|c|}{ Calorie intake } & \multirow{2}{*}{$\begin{array}{c}\text { Consumed } \\
\text { rice in } \mathrm{kg} \\
(4)\end{array}$} \\
\hline & $\begin{array}{l}\text { Total } \\
(1)\end{array}$ & $\begin{array}{l}\text { From non rice } \\
\qquad(2)\end{array}$ & $\begin{array}{l}\text { From rice } \\
\quad(3)\end{array}$ & \\
\hline Year 2010 & $\begin{array}{c}13.70 \\
(41.47)\end{array}$ & $\begin{array}{c}142.52^{* * *} \\
(25.42)\end{array}$ & $\begin{array}{l}-128.82^{* * *} \\
(25.98)\end{array}$ & $\begin{array}{c}-1.14^{* * *} \\
(0.23)\end{array}$ \\
\hline Buyer & $\begin{array}{c}-217.49^{* * *} \\
(29.99)\end{array}$ & $\begin{array}{c}-101.14^{* * *} \\
(16.37)\end{array}$ & $\begin{array}{c}-116.35^{* * *} \\
(19.96)\end{array}$ & $\begin{array}{c}-1.03^{* * *} \\
(0.18)\end{array}$ \\
\hline DD estimate & $\begin{array}{c}53.05 \\
(38.07)\end{array}$ & $\begin{array}{c}3.70 \\
(21.92)\end{array}$ & $\begin{array}{l}49.35^{*} \\
(25.42)\end{array}$ & $\begin{array}{l}0.44^{*} \\
(0.22)\end{array}$ \\
\hline Income per capita & $12.12^{*}$ & $10.94^{* *}$ & 1.18 & $\begin{array}{c}0.01 \\
(0.02)\end{array}$ \\
\hline $\begin{array}{l}(2010 \text { Tk.1,000) } \\
\text { Age of household }\end{array}$ & $\begin{array}{l}(7.28) \\
-1.53^{* *}\end{array}$ & $\begin{array}{c}(5.47) \\
-1.46^{* * *}\end{array}$ & $\begin{array}{l}(2.05) \\
-0.08\end{array}$ & $\begin{array}{l}(0.02) \\
-0.00\end{array}$ \\
\hline $\begin{array}{l}\text { head } \\
\text { Female head }\end{array}$ & $\begin{array}{c}(0.64) \\
93.59^{* * *} \\
(29.51)\end{array}$ & $\begin{array}{c}(0.34) \\
130.41^{* * *} \\
(16.70)\end{array}$ & $\begin{array}{c}(0.46) \\
-36.82^{*} \\
(20.11)\end{array}$ & $\begin{array}{l}(0.00) \\
-0.32^{*} \\
(0.18)\end{array}$ \\
\hline $\begin{array}{l}\text { Household head has } \\
\text { primary education }\end{array}$ & $\begin{array}{l}45.19^{* *} \\
(18.18)\end{array}$ & $\begin{array}{c}54.22^{* * *} \\
(10.25)\end{array}$ & $\begin{array}{c}-9.03 \\
(12.96)\end{array}$ & $\begin{array}{l}-0.08 \\
(0.11)\end{array}$ \\
\hline $\begin{array}{l}\text { Household head has } \\
\text { secondary education }\end{array}$ & $\begin{array}{l}-17.85 \\
(19.62)\end{array}$ & $\begin{array}{c}48.63^{* * *} \\
(11.15)\end{array}$ & $\begin{array}{c}-66.48^{* * *} \\
(13.91)\end{array}$ & $\begin{array}{c}-0.59^{* * *} \\
(0.12)\end{array}$ \\
\hline Household head has & $\begin{array}{l}20.75 \\
(40.62)\end{array}$ & $\begin{array}{c}135.81^{* * *} \\
(28.34)\end{array}$ & $\begin{array}{l}-115.06^{* * *} \\
(24.43)\end{array}$ & $\begin{array}{l}-1.01^{* * *} \\
(0.22)\end{array}$ \\
\hline $\begin{array}{l}\text { Household head has } \\
\text { graduate degree }\end{array}$ & $\begin{array}{l}-123.77 \\
(77.12)\end{array}$ & $\begin{array}{c}118.56^{* *} \\
(46.03)\end{array}$ & $\begin{array}{c}-242.34^{* * *} \\
(53.85)\end{array}$ & $\begin{array}{c}-2.14^{* * *} \\
(0.47)\end{array}$ \\
\hline $\begin{array}{l}\text { Household head has } \\
\text { other education }\end{array}$ & $\begin{array}{c}52.30 \\
(169.29)\end{array}$ & $\begin{array}{c}29.70 \\
(109.02)\end{array}$ & $\begin{array}{c}22.61 \\
(110.73)\end{array}$ & $\begin{array}{c}0.20 \\
(0.98)\end{array}$ \\
\hline $\begin{array}{l}\text { Spouse with primary } \\
\text { education }\end{array}$ & $\begin{array}{c}-9.62 \\
(16.76)\end{array}$ & $\begin{array}{c}40.74^{* * *} \\
(10.22)\end{array}$ & $\begin{array}{c}-50.36^{* * *} \\
(12.05)\end{array}$ & $\begin{array}{c}-0.44^{* * *} \\
(0.11)\end{array}$ \\
\hline $\begin{array}{l}\text { Spouse with } \\
\text { secondary education }\end{array}$ & $\begin{array}{l}20.34 \\
(20.30)\end{array}$ & $\begin{array}{c}91.06^{* * *} \\
(12.84)\end{array}$ & $\begin{array}{c}-70.72^{* * *} \\
(13.67)\end{array}$ & $\begin{array}{c}-0.62^{* * *} \\
(0.12)\end{array}$ \\
\hline $\begin{array}{l}\text { Spouse with higher } \\
\text { secondary education }\end{array}$ & $\begin{array}{l}-11.34 \\
(67.01)\end{array}$ & $\begin{array}{c}129.90^{* * *} \\
(39.89)\end{array}$ & $\begin{array}{c}-141.24^{* * *} \\
(44.58)\end{array}$ & $\begin{array}{c}-1.25^{* * *} \\
(0.39)\end{array}$ \\
\hline $\begin{array}{l}\text { Spouse with graduate } \\
\text { degree }\end{array}$ & $\begin{array}{l}-353.27^{*} \\
(206.07)\end{array}$ & $\begin{array}{c}184.11 \\
(170.91)\end{array}$ & $\begin{array}{c}-537.38^{* * *} \\
(123.68)\end{array}$ & $\begin{array}{c}-4.74^{* * *} \\
(1.09)\end{array}$ \\
\hline $\begin{array}{l}\text { Spouse with other } \\
\text { education }\end{array}$ & $\begin{array}{c}24.50 \\
(126.16)\end{array}$ & $\begin{array}{c}45.03 \\
(90.75)\end{array}$ & $\begin{array}{l}-20.52 \\
(95.99)\end{array}$ & $\begin{array}{l}-0.18 \\
(0.85)\end{array}$ \\
\hline Lean Season & $\begin{array}{l}-41.82 \\
(27.19)\end{array}$ & $\begin{array}{l}-19.20 \\
(20.80)\end{array}$ & $\begin{array}{l}-22.61 \\
(18.54)\end{array}$ & $\begin{array}{l}-0.20 \\
(0.16)\end{array}$ \\
\hline $\begin{array}{l}\text { Agricultural asset } \\
\text { per capita }(2010 \mathrm{Tk} .1,000)\end{array}$ & $\begin{array}{c}4.20^{* * *} \\
(1.20)\end{array}$ & $\begin{array}{c}1.87^{* * *} \\
(0.54)\end{array}$ & $\begin{array}{c}2.33^{* * *} \\
(0.77)\end{array}$ & $\begin{array}{c}0.02^{* * *} \\
(0.01)\end{array}$ \\
\hline Constant & $\begin{array}{c}2856.77^{* * *} \\
(103.44)\end{array}$ & $\begin{array}{l}949.46^{* * *} \\
(51.69)\end{array}$ & $\begin{array}{c}1907.31^{* * *} \\
(70.33)\end{array}$ & $\begin{array}{c}16.81^{* * *} \\
(0.62)\end{array}$ \\
\hline $\begin{array}{l}\text { Adjusted } R^{2} \\
N\end{array}$ & $\begin{array}{c}0.220 \\
10.772\end{array}$ & $\begin{array}{c}0.311 \\
10.772\end{array}$ & $\begin{array}{c}0.224 \\
10.772\end{array}$ & $\begin{array}{c}0.224 \\
10.772\end{array}$ \\
\hline
\end{tabular}

Note: Standard errors in parentheses. Models include district fixed effects and employ clustered standard errors. Bootstrapped standard errors indicate similar results.

Spouse relates to household head.

${ }^{*} p<0.10,{ }^{* *} p<0.05,{ }^{* * *} p<0.01$. 
TABLE 4: Implied significance level of the DD estimates

\begin{tabular}{ccccc}
\hline & \multicolumn{3}{c}{ Calorie intake } & $\begin{array}{c}\text { Consumed } \\
\text { rice in kg }\end{array}$ \\
\cline { 2 - 4 } & $\begin{array}{c}\text { Total } \\
(1)\end{array}$ & $\begin{array}{c}\text { From non rice } \\
(2)\end{array}$ & $\begin{array}{c}\text { From rice } \\
(3)\end{array}$ & $(4)$ \\
\hline Buyer & 0.05 & 0.05 & 0.05 & 0.04 \\
Seller & 0.06 & 0.05 & 0.04 & 0.05
\end{tabular}

Note: For simulation, we employed the analysis sample with 1,000 repetitions. Models include district fixed effects and employ clustered standard errors. 
TABLE 5: Effect of the 2005-2010 rice price increase on Buyers' food diversity

\begin{tabular}{|c|c|c|c|c|}
\hline & $\begin{array}{l}\text { HDDS } \\
(1)\end{array}$ & $\begin{array}{l}\text { FCS } \\
(2)\end{array}$ & $\begin{array}{c}\text { Items } \\
(3)\end{array}$ & $\begin{array}{c}\text { Food types } \\
\text { (4) }\end{array}$ \\
\hline Year 2010 & $\begin{array}{l}0.19^{* *} \\
(0.08)\end{array}$ & $\begin{array}{l}-0.22 \\
(0.88)\end{array}$ & $\begin{array}{c}0.75 \\
(0.53)\end{array}$ & $\begin{array}{c}0.60^{* * *} \\
(0.17)\end{array}$ \\
\hline Buyer & $\begin{array}{c}-0.30^{* * *} \\
(0.06)\end{array}$ & $\begin{array}{c}-4.05^{* * *} \\
(0.66)\end{array}$ & $\begin{array}{c}-2.38^{* * *} \\
(0.35)\end{array}$ & $\begin{array}{c}-0.69^{* * *} \\
(0.11)\end{array}$ \\
\hline DD estimate & $\begin{array}{l}-0.08 \\
(0.08)\end{array}$ & $\begin{array}{l}-0.08 \\
(0.84)\end{array}$ & $\begin{array}{l}-0.03 \\
(0.44)\end{array}$ & $\begin{array}{l}-0.04 \\
(0.14)\end{array}$ \\
\hline $\begin{array}{l}\text { Income per capita } \\
(2010 \text { Tk.1,000) }\end{array}$ & $\begin{array}{l}0.02^{* *} \\
(0.01)\end{array}$ & $\begin{array}{l}0.23^{* *} \\
(0.11)\end{array}$ & $\begin{array}{l}0.13^{*} \\
(0.07)\end{array}$ & $\begin{array}{l}0.04^{* *} \\
(0.02)\end{array}$ \\
\hline $\begin{array}{l}\text { Age of household } \\
\text { head }\end{array}$ & $\begin{array}{c}0.01^{* * *} \\
(0.00)\end{array}$ & $\begin{array}{c}0.18^{* * *} \\
(0.01)\end{array}$ & $\begin{array}{c}0.11^{* * *} \\
(0.01)\end{array}$ & $\begin{array}{c}0.02^{* * *} \\
(0.00)\end{array}$ \\
\hline Female head & $\begin{array}{c}-0.23^{* * *} \\
(0.06)\end{array}$ & $\begin{array}{l}-0.83 \\
(0.62)\end{array}$ & $\begin{array}{c}-2.77^{* * *} \\
(0.36)\end{array}$ & $\begin{array}{c}-0.37^{* * *} \\
(0.11)\end{array}$ \\
\hline $\begin{array}{l}\text { Household head has } \\
\text { primary education }\end{array}$ & $\begin{array}{c}0.29^{* * *} \\
(0.04)\end{array}$ & $\begin{array}{c}2.56^{* * *} \\
(0.40)\end{array}$ & $\begin{array}{c}1.77^{* * *} \\
(0.23)\end{array}$ & $\begin{array}{c}0.49^{* * *} \\
(0.08)\end{array}$ \\
\hline $\begin{array}{l}\text { Household head has } \\
\text { secondary education }\end{array}$ & $\begin{array}{c}0.30^{* * *} \\
(0.05)\end{array}$ & $\begin{array}{c}3.57^{* * *} \\
(0.45)\end{array}$ & $\begin{array}{c}2.12^{* * *} \\
(0.26)\end{array}$ & $\begin{array}{c}0.65^{* * *} \\
(0.08)\end{array}$ \\
\hline $\begin{array}{l}\text { Household head has } \\
\text { higher secondary education }\end{array}$ & $\begin{array}{c}0.45^{* * *} \\
(0.08)\end{array}$ & $\begin{array}{c}7.20^{* * *} \\
(1.01)\end{array}$ & $\begin{array}{c}2.62^{* * *} \\
(0.54)\end{array}$ & $\begin{array}{c}0.91^{* * *} \\
(0.16)\end{array}$ \\
\hline $\begin{array}{l}\text { Household head has } \\
\text { graduate degree }\end{array}$ & $\begin{array}{c}0.57^{* * *} \\
(0.16)\end{array}$ & $\begin{array}{l}8.68^{* * *} \\
(1.96)\end{array}$ & $\begin{array}{l}3.77^{* * *} \\
(1.17)\end{array}$ & $\begin{array}{c}1.27^{* * *} \\
(0.30)\end{array}$ \\
\hline $\begin{array}{l}\text { Household head has } \\
\text { other education }\end{array}$ & $\begin{array}{c}0.01 \\
(0.43)\end{array}$ & $\begin{array}{l}-0.07 \\
(3.79)\end{array}$ & $\begin{array}{l}2.06 \\
(2.42)\end{array}$ & $\begin{array}{c}0.12 \\
(0.73)\end{array}$ \\
\hline $\begin{array}{l}\text { Spouse with primary } \\
\text { education }\end{array}$ & $\begin{array}{c}0.21^{* * *} \\
(0.04)\end{array}$ & $\begin{array}{l}1.99^{* * *} \\
(0.41)\end{array}$ & $\begin{array}{c}1.03^{* * *} \\
(0.23)\end{array}$ & $\begin{array}{c}0.43^{* * *} \\
(0.07)\end{array}$ \\
\hline $\begin{array}{l}\text { Spouse with } \\
\text { secondary education }\end{array}$ & $\begin{array}{c}0.43^{* * *} \\
(0.04)\end{array}$ & $\begin{array}{l}4.82^{* * *} \\
(0.45)\end{array}$ & $\begin{array}{c}2.28^{* * *} \\
(0.26)\end{array}$ & $\begin{array}{c}0.82^{* * *} \\
(0.08)\end{array}$ \\
\hline $\begin{array}{l}\text { Spouse with higher } \\
\text { secondary education }\end{array}$ & $\begin{array}{c}0.64^{* * *} \\
(0.13)\end{array}$ & $\begin{array}{c}9.40^{* * *} \\
(1.58)\end{array}$ & $\begin{array}{c}3.74^{* * *} \\
(0.86)\end{array}$ & $\begin{array}{l}1.19^{* * *} \\
(0.25)\end{array}$ \\
\hline $\begin{array}{l}\text { Spouse with graduate } \\
\text { degree }\end{array}$ & $\begin{array}{c}1.46^{* * *} \\
(0.21)\end{array}$ & $\begin{array}{c}19.44^{* * *} \\
(2.37)\end{array}$ & $\begin{array}{c}7.83^{* * *} \\
(2.97)\end{array}$ & $\begin{array}{c}3.25^{* * *} \\
(0.58)\end{array}$ \\
\hline $\begin{array}{l}\text { Spouse with other } \\
\text { education }\end{array}$ & $\begin{array}{l}-0.23 \\
(0.26)\end{array}$ & $\begin{array}{l}-2.41 \\
(2.70)\end{array}$ & $\begin{array}{l}-2.23 \\
(2.00)\end{array}$ & $\begin{array}{l}-0.13 \\
(0.41)\end{array}$ \\
\hline Lean Season & $\begin{array}{l}0.16^{*} \\
(0.09)\end{array}$ & $\begin{array}{c}0.96 \\
(0.80)\end{array}$ & $\begin{array}{c}0.83 \\
(0.57)\end{array}$ & $\begin{array}{l}0.44^{* *} \\
(0.19)\end{array}$ \\
\hline $\begin{array}{l}\text { Agricultural asset } \\
\text { per capita }(2010 \mathrm{Tk} .1,000)\end{array}$ & $\begin{array}{c}0.01^{* * *} \\
(0.00)\end{array}$ & $\begin{array}{l}0.06^{*} \\
(0.03)\end{array}$ & $\begin{array}{l}0.05^{* *} \\
(0.02)\end{array}$ & $\begin{array}{c}0.01^{* * *} \\
(0.00)\end{array}$ \\
\hline Constant & $\begin{array}{c}8.36^{* * *} \\
(0.17)\end{array}$ & $\begin{array}{c}53.63^{* * *} \\
(1.51)\end{array}$ & $\begin{array}{c}25.24^{* * *} \\
(0.85)\end{array}$ & $\begin{array}{c}7.63^{* * *} \\
(0.29)\end{array}$ \\
\hline $\begin{array}{l}\text { Adjusted } \mathrm{R}^{2} \\
\mathrm{~N}\end{array}$ & $\begin{array}{c}0.220 \\
10.772\end{array}$ & $\begin{array}{c}0.240 \\
10.772\end{array}$ & $\begin{array}{c}0.279 \\
10.772\end{array}$ & $\begin{array}{c}0.269 \\
10.772\end{array}$ \\
\hline
\end{tabular}

Note: See footnotes in Table 3. 
TABLE 6: Effect of the 2005-2010 rice price increase on Buyers' consumption by types of food categories

\begin{tabular}{|c|c|c|c|c|c|c|}
\hline & \multicolumn{6}{|c|}{ Calorie intake (Kcal. per capita per day) from } \\
\hline & $\begin{array}{c}\text { Grain } \\
(1)\end{array}$ & $\begin{array}{l}\text { Non rice } \\
\text { grain } \\
(2)\end{array}$ & $\begin{array}{c}\text { Pulses } \\
\text { (3) }\end{array}$ & $\begin{array}{c}\text { Protein } \\
\text { (4) }\end{array}$ & $\begin{array}{c}\text { Fruits } \\
(5)\end{array}$ & $\begin{array}{c}\text { Other } \\
\text { items } \\
(6)\end{array}$ \\
\hline Year 2010 & $\begin{array}{l}-45.92 \\
(27.92)\end{array}$ & $\begin{array}{c}82.90^{* * *} \\
(11.20)\end{array}$ & $\begin{array}{c}2.61 \\
(2.92)\end{array}$ & $\begin{array}{c}8.31 \\
(5.38)\end{array}$ & $\begin{array}{c}17.35^{* *} \\
(7.09)\end{array}$ & $\begin{array}{c}28.50^{* * *} \\
(8.32)\end{array}$ \\
\hline Buyer & $\begin{array}{c}-132.87^{* * *} \\
(21.32)\end{array}$ & $\begin{array}{c}-16.53^{* *} \\
(6.57)\end{array}$ & $\begin{array}{l}-4.20^{* *} \\
(1.94)\end{array}$ & $\begin{array}{c}-29.17^{* * *} \\
(3.78)\end{array}$ & $\begin{array}{c}-13.98^{* * *} \\
(4.16)\end{array}$ & $\begin{array}{c}-31.01^{* * *} \\
(5.47)\end{array}$ \\
\hline DD estimate & $\begin{array}{l}49.24^{*} \\
(26.98)\end{array}$ & $\begin{array}{l}-0.11 \\
(9.96)\end{array}$ & $\begin{array}{l}-0.23 \\
(2.57)\end{array}$ & $\begin{array}{c}0.45 \\
(5.13)\end{array}$ & $\begin{array}{l}-4.28 \\
(5.49)\end{array}$ & $\begin{array}{c}7.58 \\
(7.17)\end{array}$ \\
\hline $\begin{array}{l}\text { Income per capita } \\
(2010 \text { Tk.1,000) }\end{array}$ & $\begin{array}{l}3.86 \\
(3.17)\end{array}$ & $\begin{array}{l}2.68^{* *} \\
(1.29)\end{array}$ & $\begin{array}{l}0.44^{*} \\
(0.26)\end{array}$ & $\begin{array}{l}2.58^{*} \\
(1.31)\end{array}$ & $\begin{array}{l}1.39^{* *} \\
(0.67)\end{array}$ & $\begin{array}{l}3.25^{*} \\
(1.70)\end{array}$ \\
\hline $\begin{array}{l}\text { Age of household } \\
\text { head }\end{array}$ & $\begin{array}{l}-0.11 \\
(0.47)\end{array}$ & $\begin{array}{l}-0.03 \\
(0.16)\end{array}$ & $\begin{array}{l}-0.01 \\
(0.04)\end{array}$ & $\begin{array}{l}-0.08 \\
(0.08)\end{array}$ & $\begin{array}{c}-0.59^{* * *} \\
(0.09)\end{array}$ & $\begin{array}{c}-0.60^{* * *} \\
(0.12)\end{array}$ \\
\hline Female head & $\begin{array}{l}-14.09 \\
(21.55)\end{array}$ & $\begin{array}{c}22.73^{* * *} \\
(8.39)\end{array}$ & $\begin{array}{r}7.66^{* * *} \\
(1.98)\end{array}$ & $\begin{array}{c}15.09^{* * *} \\
(3.90)\end{array}$ & $\begin{array}{c}28.50^{* * *} \\
(3.53)\end{array}$ & $\begin{array}{c}48.06^{* * *} \\
(5.38)\end{array}$ \\
\hline $\begin{array}{l}\text { Household head has } \\
\text { primary education }\end{array}$ & $\begin{array}{c}2.31 \\
(13.93)\end{array}$ & $\begin{array}{c}11.35^{* *} \\
(4.85)\end{array}$ & $\begin{array}{c}1.17 \\
(1.27)\end{array}$ & $\begin{array}{c}14.42^{* * *} \\
(2.26)\end{array}$ & $\begin{array}{l}5.72^{* *} \\
(2.40)\end{array}$ & $\begin{array}{c}18.86^{* * *} \\
(3.43)\end{array}$ \\
\hline $\begin{array}{l}\text { Household head has } \\
\text { secondary education }\end{array}$ & $\begin{array}{c}-52.99^{* * *} \\
(14.80)\end{array}$ & $\begin{array}{c}13.49^{* * *} \\
(5.12)\end{array}$ & $\begin{array}{c}1.30 \\
(1.15)\end{array}$ & $\begin{array}{c}12.49^{* * *} \\
(2.56)\end{array}$ & $\begin{array}{l}-0.23 \\
(2.55)\end{array}$ & $\begin{array}{c}19.27^{* * *} \\
(3.78)\end{array}$ \\
\hline $\begin{array}{l}\text { Household head has } \\
\text { higher secondary education }\end{array}$ & $\begin{array}{c}-83.86^{* * *} \\
(27.15)\end{array}$ & $\begin{array}{c}31.21^{* * *} \\
(11.67)\end{array}$ & $\begin{array}{c}7.32^{* * *} \\
(2.76)\end{array}$ & $\begin{array}{c}40.52^{* * *} \\
(7.17)\end{array}$ & $\begin{array}{c}18.75^{* * *} \\
(7.06)\end{array}$ & $\begin{array}{c}34.90^{* * *} \\
(8.22)\end{array}$ \\
\hline $\begin{array}{l}\text { Household head has } \\
\text { graduate degree }\end{array}$ & $\begin{array}{c}-220.45^{* * *} \\
(57.91)\end{array}$ & $\begin{array}{c}21.89 \\
(14.95)\end{array}$ & $\begin{array}{l}-0.08 \\
(4.71)\end{array}$ & $\begin{array}{c}38.34^{* * *} \\
(10.48)\end{array}$ & $\begin{array}{l}-2.06 \\
(15.75)\end{array}$ & $\begin{array}{c}56.65^{* * *} \\
(15.86)\end{array}$ \\
\hline $\begin{array}{l}\text { Household head has } \\
\text { other education }\end{array}$ & $\begin{array}{l}-1.18 \\
(95.67)\end{array}$ & $\begin{array}{l}-23.78 \\
(44.86)\end{array}$ & $\begin{array}{c}-16.98^{* * *} \\
(4.87)\end{array}$ & $\begin{array}{c}33.34 \\
(32.75)\end{array}$ & $\begin{array}{c}29.93 \\
(23.43)\end{array}$ & $\begin{array}{c}3.38 \\
(37.31)\end{array}$ \\
\hline $\begin{array}{l}\text { Spouse with primary } \\
\text { education }\end{array}$ & $\begin{array}{c}-39.38^{* * *} \\
(12.69)\end{array}$ & $\begin{array}{c}10.97^{* *} \\
(4.82)\end{array}$ & $\begin{array}{c}1.10 \\
(1.33)\end{array}$ & $\begin{array}{c}7.82^{* * *} \\
(2.38)\end{array}$ & $\begin{array}{l}4.09^{*} \\
(2.39)\end{array}$ & $\begin{array}{c}14.74^{* * *} \\
(3.67)\end{array}$ \\
\hline $\begin{array}{l}\text { Spouse with } \\
\text { secondary education }\end{array}$ & $\begin{array}{c}-50.06^{* * *} \\
(14.23)\end{array}$ & $\begin{array}{c}20.66^{* * *} \\
(5.55)\end{array}$ & $\begin{array}{l}3.33^{* *} \\
(1.37)\end{array}$ & $\begin{array}{c}22.31^{* * *} \\
(2.86)\end{array}$ & $\begin{array}{c}7.93^{* * *} \\
(2.68)\end{array}$ & $\begin{array}{c}33.20^{* * *} \\
(4.52)\end{array}$ \\
\hline $\begin{array}{l}\text { Spouse with higher } \\
\text { secondary education }\end{array}$ & $\begin{array}{c}-122.34^{* * *} \\
(47.15)\end{array}$ & $\begin{array}{c}18.90 \\
(14.80)\end{array}$ & $\begin{array}{l}-1.39 \\
(5.19)\end{array}$ & $\begin{array}{c}45.48^{* * *} \\
(9.64)\end{array}$ & $\begin{array}{c}-0.92 \\
(10.06)\end{array}$ & $\begin{array}{c}65.07^{* * *} \\
(13.90)\end{array}$ \\
\hline $\begin{array}{l}\text { Spouse with graduate } \\
\text { degree }\end{array}$ & $\begin{array}{c}-442.34^{* * *} \\
(134.08)\end{array}$ & $\begin{array}{c}95.04 \\
(64.59)\end{array}$ & $\begin{array}{l}-21.13^{*} \\
(11.76)\end{array}$ & $\begin{array}{l}99.85^{* *} \\
(41.16)\end{array}$ & $\begin{array}{l}-14.47 \\
(37.45)\end{array}$ & $\begin{array}{c}27.00 \\
(39.83)\end{array}$ \\
\hline $\begin{array}{l}\text { Spouse with other } \\
\text { education }\end{array}$ & $\begin{array}{c}-23.48 \\
(100.93)\end{array}$ & $\begin{array}{l}-2.96 \\
(29.62)\end{array}$ & $\begin{array}{l}-12.66 \\
(12.84)\end{array}$ & $\begin{array}{c}58.85^{* * *} \\
(19.11)\end{array}$ & $\begin{array}{c}1.15 \\
(24.60)\end{array}$ & $\begin{array}{l}18.78 \\
(23.21)\end{array}$ \\
\hline Lean Season & $\begin{array}{c}-31.74^{*} \\
(18.63)\end{array}$ & $\begin{array}{l}-9.13 \\
(9.98)\end{array}$ & $\begin{array}{c}10.23^{* * *} \\
(2.91)\end{array}$ & $\begin{array}{c}3.42 \\
(4.11)\end{array}$ & $\begin{array}{c}-25.28^{* * *} \\
(4.76)\end{array}$ & $\begin{array}{c}9.38 \\
(7.59)\end{array}$ \\
\hline $\begin{array}{l}\text { Agricultural asset } \\
\text { per capita (2010 Tk.1,000) }\end{array}$ & $\begin{array}{c}2.56^{* * *} \\
(0.70)\end{array}$ & $\begin{array}{c}0.23 \\
(0.23)\end{array}$ & $\begin{array}{c}0.08 \\
(0.06)\end{array}$ & $\begin{array}{l}0.40^{* *} \\
(0.18)\end{array}$ & $\begin{array}{l}0.45^{* *} \\
(0.20)\end{array}$ & $\begin{array}{c}0.63^{* * *} \\
(0.13)\end{array}$ \\
\hline Constant & $\begin{array}{c}1965.55^{* * *} \\
(73.56)\end{array}$ & $\begin{array}{c}58.24^{* * *} \\
(17.23)\end{array}$ & $\begin{array}{c}62.22^{* * *} \\
(6.81)\end{array}$ & $\begin{array}{c}129.52^{* * *} \\
(12.55)\end{array}$ & $\begin{array}{c}289.63^{* * *} \\
(13.78)\end{array}$ & $\begin{array}{c}294.94^{* * *} \\
(19.84)\end{array}$ \\
\hline Adjusted $\mathrm{R}^{2}$ & 0.215 & 0.230 & 0.270 & 0.219 & 0.274 & 0.286 \\
\hline $\mathrm{N}$ & 10,772 & 10,772 & 10,772 & 10,772 & 10,772 & 10,772 \\
\hline
\end{tabular}

Note: See footnotes in Table 3. 
TABLE 7: Effect of the 2005-2010 rice price increase on the Buyers' consumption of high and low value items

\begin{tabular}{lcccc}
\hline & \multicolumn{4}{c}{ Calorie intake (Kcal. per capita per day) from } \\
\cline { 2 - 5 } & High value pulses & Low value pulses & High value fish & Low value fish \\
& $(1)$ & $(2)$ & $(3)$ & $(4)$ \\
\hline Year 2010 & 1.05 & 1.56 & $-3.10^{* *}$ & $9.75^{* * *}$ \\
& $(2.25)$ & $(1.75)$ & $(1.50)$ & $(1.80)$ \\
Buyer & $-3.77^{* *}$ & -0.43 & $-2.61^{* * *}$ & $-7.02^{* * *}$ \\
& $(1.51)$ & $(1.21)$ & $(0.97)$ & $(1.16)$ \\
DD estimate & -0.54 & 0.31 & 2.01 & $-3.63^{* *}$ \\
& $(2.03)$ & $(1.61)$ & $(1.28)$ & $(1.66)$ \\
Constant & $41.18^{* * *}$ & $21.05^{* * *}$ & $35.27^{* * *}$ & $32.84^{* * *}$ \\
& $(5.21)$ & $(4.14)$ & $(3.91)$ & $(3.64)$ \\
Adjusted $\mathrm{R}^{2}$ & 0.325 & 0.203 & 0.225 & 0.270 \\
$\mathrm{~N}$ & 10,772 & 10,772 & 10,772 & 10,772 \\
\hline
\end{tabular}

Note: See footnotes in Table 3.

TABLE 8: Effect of the 2005-2010 rice price increase on Buyers' consumption

\begin{tabular}{lccc}
\hline & \multicolumn{3}{c}{ Log of per capita consumption value of } \\
\cline { 2 - 4 } & $\begin{array}{c}\text { Rice } \\
(1)\end{array}$ & $\begin{array}{c}\text { Non rice food items } \\
(2)\end{array}$ & $\begin{array}{c}\text { Non food items } \\
(3)\end{array}$ \\
\hline Year 2010 & $0.56^{* * *}$ & $0.64^{* * *}$ & $0.58^{* * *}$ \\
& $(0.02)$ & $(0.04)$ & $(0.04)$ \\
Buyer & $-0.05^{* * *}$ & $-0.15^{* * *}$ & $-0.23^{* * *}$ \\
& $(0.01)$ & $(0.03)$ & $(0.03)$ \\
DD estimate & 0.03 & 0.05 & 0.01 \\
& $(0.02)$ & $(0.04)$ & $(0.04)$ \\
Log(income per & 0.00 & $0.11^{* * *}$ & $0.16^{* * *}$ \\
capita) & $(0.01)$ & $(0.01)$ & $(0.01)$ \\
Constant & $5.45^{* * *}$ & $4.90^{* * *}$ & $4.37^{* * *}$ \\
& $(0.07)$ & $(0.13)$ & $(0.15)$ \\
Adjusted $\mathrm{R}^{2}$ & 0.621 & 0.654 & 0.578 \\
$\mathrm{~N}$ & 3,285 & 3,285 & 3,285 \\
\hline
\end{tabular}

Note: See footnotes in Table 3. 

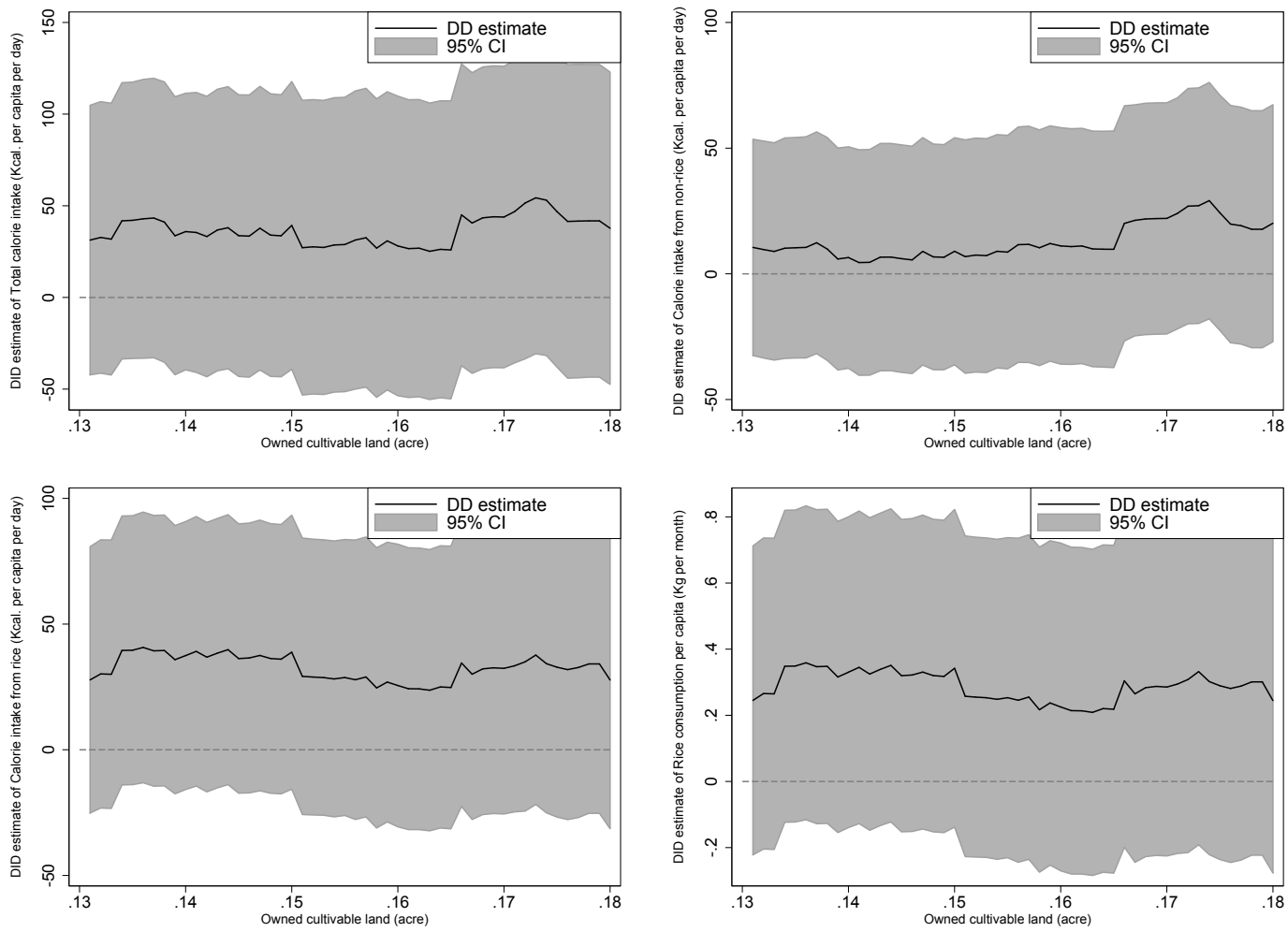

FIGURE 1: Distribution of DD estimates for Buyers
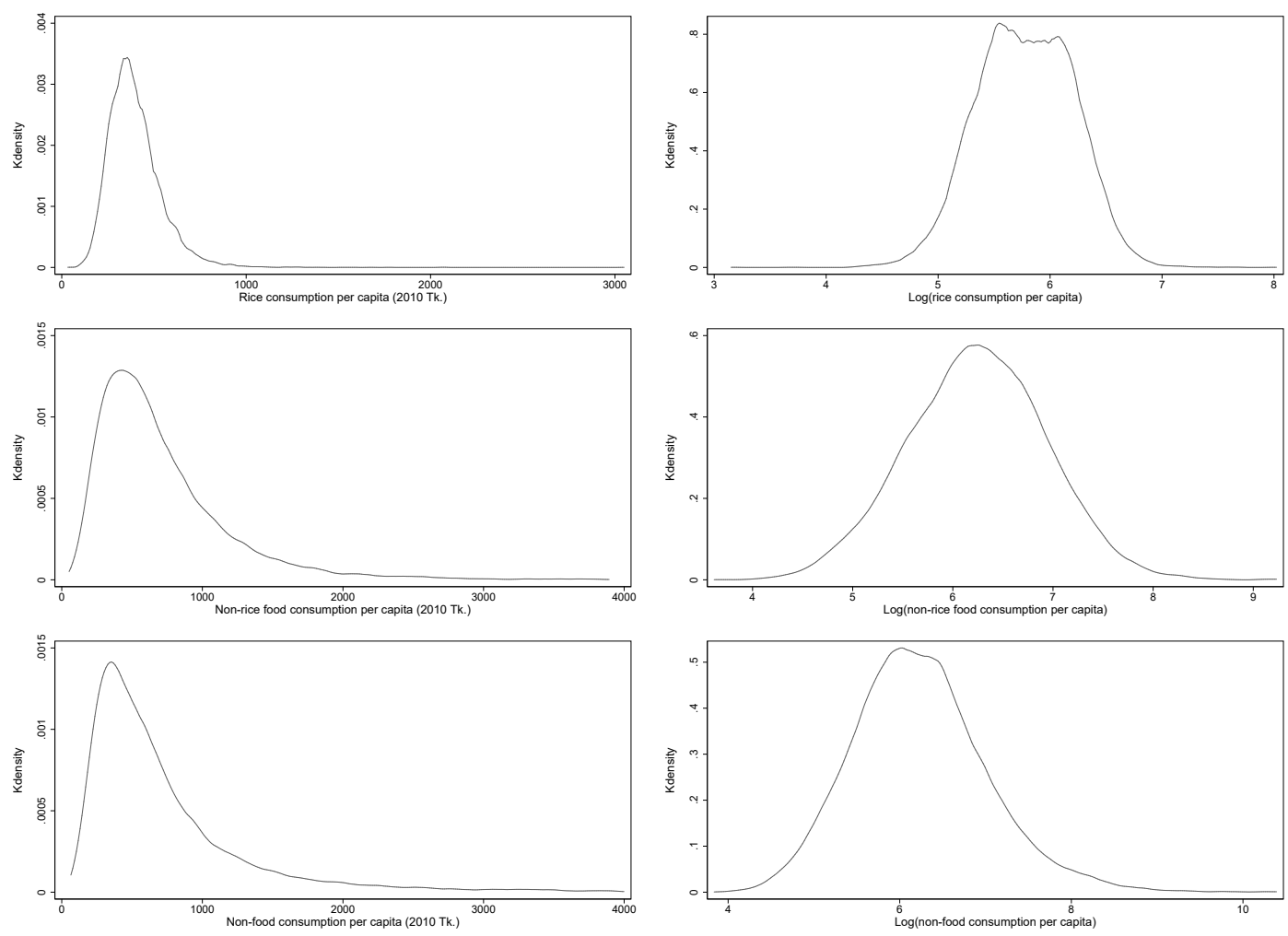

Figure 2: Kdensity of the dependent variables (level and logarithms) 


\section{Appendix A: TABles}

TABLE A.1: Effect of the 2005-2010 rice price increase on the Sellers' consumption

\begin{tabular}{|c|c|c|c|c|}
\hline & \multicolumn{3}{|c|}{ Calorie intake } & \multirow{2}{*}{$\begin{array}{c}\text { Consumed } \\
\text { rice in } \mathrm{kg} \\
\text { (4) }\end{array}$} \\
\hline & $\begin{array}{c}\text { Total } \\
(1)\end{array}$ & $\begin{array}{c}\text { From Non rice } \\
(2)\end{array}$ & $\begin{array}{c}\text { From rice } \\
\quad(3)\end{array}$ & \\
\hline Year 2010 & $\begin{array}{c}19.07 \\
(42.06)\end{array}$ & $\begin{array}{c}158.11^{* * *} \\
(26.33)\end{array}$ & $\begin{array}{c}-139.04^{* * *} \\
(26.16)\end{array}$ & $\begin{array}{c}-1.23^{* * *} \\
(0.23)\end{array}$ \\
\hline Seller & $\begin{array}{l}197.64^{* * *} \\
(53.04)\end{array}$ & $\begin{array}{c}115.33^{* * *} \\
(28.94)\end{array}$ & $\begin{array}{l}82.32^{* *} \\
(34.15)\end{array}$ & $\begin{array}{l}0.73^{* *} \\
(0.30)\end{array}$ \\
\hline DD estimate & $\begin{array}{r}143.38^{*} \\
(79.80)\end{array}$ & $\begin{array}{l}75.75^{*} \\
(45.47)\end{array}$ & $\begin{array}{c}67.63 \\
(50.49)\end{array}$ & $\begin{array}{c}0.60 \\
(0.45)\end{array}$ \\
\hline $\begin{array}{l}\text { Income per capita } \\
(2010 \text { Tk. } 1,000)\end{array}$ & $\begin{array}{l}3.23 \\
(2.31)\end{array}$ & $\begin{array}{l}3.30^{* *} \\
(1.64)\end{array}$ & $\begin{array}{l}-0.06 \\
(1.08)\end{array}$ & $\begin{array}{l}-0.00 \\
(0.01)\end{array}$ \\
\hline Age of household & -0.86 & 0.29 & -1.15 & -0.01 \\
\hline $\begin{array}{l}\text { head } \\
\text { Female head }\end{array}$ & $\begin{array}{c}(1.40) \\
118.83^{*} \\
(65.34)\end{array}$ & $\begin{array}{c}(0.76) \\
168.16^{* * *} \\
(34.86)\end{array}$ & $\begin{array}{c}(0.98) \\
-49.33 \\
(45.64)\end{array}$ & $\begin{array}{c}(0.01) \\
-0.43 \\
(0.40)\end{array}$ \\
\hline $\begin{array}{l}\text { Household head has } \\
\text { primary education }\end{array}$ & $\begin{array}{c}108.95^{* *} \\
(49.28)\end{array}$ & $\begin{array}{l}60.85^{* *} \\
(26.80)\end{array}$ & $\begin{array}{c}48.04) \\
48.09 \\
(33.23)\end{array}$ & $\begin{array}{c}(0.40) \\
0.42 \\
(0.29)\end{array}$ \\
\hline $\begin{array}{l}\text { Household head has } \\
\text { secondary education }\end{array}$ & $\begin{array}{c}7.68 \\
(43.10)\end{array}$ & $\begin{array}{l}40.31^{*} \\
(23.47)\end{array}$ & $\begin{array}{l}-32.64 \\
(28.54)\end{array}$ & $\begin{array}{l}-0.29 \\
(0.25)\end{array}$ \\
\hline Household head has & 66.37 & $109.05^{* *}$ & -42.67 & -0.38 \\
\hline higher secondary education & $(76.43)$ & $(42.98)$ & $(47.36)$ & $(0.42)$ \\
\hline $\begin{array}{l}\text { Household head has } \\
\text { graduate degree }\end{array}$ & $\begin{array}{l}-143.29 \\
(109.48)\end{array}$ & $\begin{array}{l}54.21 \\
(54.98)\end{array}$ & $\begin{array}{c}-197.50^{* *} \\
(77.53)\end{array}$ & $\begin{array}{c}-1.74^{* *} \\
(0.68)\end{array}$ \\
\hline $\begin{array}{l}\text { Household head has } \\
\text { other education }\end{array}$ & $\begin{array}{c}-7.86 \\
(269.68)\end{array}$ & $\begin{array}{l}-183.26 \\
(121.62)\end{array}$ & $\begin{array}{l}175.40 \\
(203.97)\end{array}$ & $\begin{array}{c}1.55 \\
(1.80)\end{array}$ \\
\hline $\begin{array}{l}\text { Spouse with primary } \\
\text { education }\end{array}$ & $\begin{array}{l}-54.31 \\
(43.59)\end{array}$ & $\begin{array}{l}38.42 \\
(23.34)\end{array}$ & $\begin{array}{c}-92.72^{* * *} \\
(29.14)\end{array}$ & $\begin{array}{c}-0.82^{* * *} \\
(0.26)\end{array}$ \\
\hline $\begin{array}{l}\text { Spouse with } \\
\text { secondary education }\end{array}$ & $\begin{array}{l}-67.72 \\
(50.13)\end{array}$ & $\begin{array}{c}77.08^{* * *} \\
(27.26)\end{array}$ & $\begin{array}{c}-144.81^{* * *} \\
(32.76)\end{array}$ & $\begin{array}{c}-1.28^{* * *} \\
(0.29)\end{array}$ \\
\hline $\begin{array}{l}\text { Spouse with higher } \\
\text { secondary education }\end{array}$ & $\begin{array}{r}-181.25^{*} \\
(95.77)\end{array}$ & $\begin{array}{l}81.62 \\
(57.81)\end{array}$ & $\begin{array}{c}-262.87^{* * *} \\
(61.82)\end{array}$ & $\begin{array}{c}-2.32^{* * *} \\
(0.54)\end{array}$ \\
\hline $\begin{array}{l}\text { Spouse with graduate } \\
\text { degree }\end{array}$ & $\begin{array}{l}-727.46 \\
(525.24)\end{array}$ & $\begin{array}{c}-295.55^{* *} \\
(123.31)\end{array}$ & $\begin{array}{l}-431.91 \\
(464.34)\end{array}$ & $\begin{array}{l}-3.81 \\
(4.09)\end{array}$ \\
\hline $\begin{array}{l}\text { Spouse with other } \\
\text { education }\end{array}$ & $\begin{array}{l}-46.15 \\
(186.77)\end{array}$ & $\begin{array}{c}551.15^{* * *} \\
(163.50)\end{array}$ & $\begin{array}{c}-597.29^{* * *} \\
(166.61)\end{array}$ & $\begin{array}{c}-5.27^{* * *} \\
(1.47)\end{array}$ \\
\hline Lean Season & $\begin{array}{l}-71.53 \\
(51.05)\end{array}$ & $\begin{array}{l}-24.00 \\
(32.53)\end{array}$ & $\begin{array}{l}-47.54 \\
(33.74)\end{array}$ & $\begin{array}{l}-0.42 \\
(0.30)\end{array}$ \\
\hline $\begin{array}{l}\text { Agricultural asset } \\
\text { per capita }(2010 \text { Tk.1,000) }\end{array}$ & $\begin{array}{c}7.26^{* * *} \\
(2.33)\end{array}$ & $\begin{array}{c}3.81^{* * *} \\
(1.17)\end{array}$ & $\begin{array}{l}3.45^{* *} \\
(1.52)\end{array}$ & $\begin{array}{l}0.03^{* *} \\
(0.01)\end{array}$ \\
\hline Constant & $\begin{array}{c}2649.54^{* * *} \\
(173.89)\end{array}$ & $\begin{array}{c}706.58^{* * *} \\
(95.51)\end{array}$ & $\begin{array}{c}1942.95^{* * *} \\
(121.70)\end{array}$ & $\begin{array}{c}17.13^{* * *} \\
(1.07)\end{array}$ \\
\hline Adjusted $\mathrm{R}^{2}$ & 0.226 & 0.303 & 0.200 & 0.200 \\
\hline $\mathrm{N}$ & 2,806 & 2,806 & 2,806 & 2,806 \\
\hline
\end{tabular}

Note: See footnotes in Table 3. 
TABle A.2: Effect of the 2005-2010 rice price increase on Sellers' food diversity

\begin{tabular}{|c|c|c|c|c|}
\hline & $\begin{array}{l}\text { HDDS } \\
(1)\end{array}$ & $\begin{array}{c}\text { FCS } \\
(2)\end{array}$ & $\begin{array}{l}\text { Items } \\
(3)\end{array}$ & $\begin{array}{c}\text { Food types } \\
\text { (4) }\end{array}$ \\
\hline Year 2010 & $\begin{array}{c}0.22^{* * *} \\
(0.08)\end{array}$ & $\begin{array}{c}0.45 \\
(0.84)\end{array}$ & $\begin{array}{l}1.08^{* *} \\
(0.52)\end{array}$ & $\begin{array}{c}0.72^{* * *} \\
(0.16)\end{array}$ \\
\hline Seller & $\begin{array}{c}0.31^{* * *} \\
(0.08)\end{array}$ & $\begin{array}{c}3.41^{* * *} \\
(0.88)\end{array}$ & $\begin{array}{c}1.89^{* * *} \\
(0.48)\end{array}$ & $\begin{array}{c}0.59^{* * *} \\
(0.14)\end{array}$ \\
\hline DD estimate & $\begin{array}{l}-0.13 \\
(0.11)\end{array}$ & $\begin{array}{l}-0.00 \\
(1.23)\end{array}$ & $\begin{array}{l}-0.25 \\
(0.68)\end{array}$ & $\begin{array}{l}-0.25 \\
(0.20)\end{array}$ \\
\hline $\begin{array}{l}\text { Income per capita } \\
(2010 \text { Tk.1,000) }\end{array}$ & $\begin{array}{l}0.00^{* *} \\
(0.00)\end{array}$ & $\begin{array}{l}0.06 \\
(0.04)\end{array}$ & $\begin{array}{c}0.02 \\
(0.02)\end{array}$ & $\begin{array}{l}0.01^{*} \\
(0.01)\end{array}$ \\
\hline $\begin{array}{l}\text { Age of household } \\
\text { head }\end{array}$ & $\begin{array}{c}0.01^{* * *} \\
(0.00)\end{array}$ & $\begin{array}{c}0.24^{* * *} \\
(0.02)\end{array}$ & $\begin{array}{c}0.13^{* * *} \\
(0.01)\end{array}$ & $\begin{array}{c}0.03^{* * *} \\
(0.00)\end{array}$ \\
\hline Female head & $\begin{array}{l}-0.25^{* *} \\
(0.10)\end{array}$ & $\begin{array}{l}-0.87 \\
(1.06)\end{array}$ & $\begin{array}{c}-2.36^{* * *} \\
(0.61)\end{array}$ & $\begin{array}{c}-0.52^{* * *} \\
(0.19)\end{array}$ \\
\hline $\begin{array}{l}\text { Household head has } \\
\text { primary education }\end{array}$ & $\begin{array}{l}0.16^{* *} \\
(0.07)\end{array}$ & $\begin{array}{l}1.22 \\
(0.82)\end{array}$ & $\begin{array}{c}1.35^{* * *} \\
(0.41)\end{array}$ & $\begin{array}{c}0.41^{* * *} \\
(0.14)\end{array}$ \\
\hline $\begin{array}{l}\text { Household head has } \\
\text { secondary education }\end{array}$ & $\begin{array}{c}0.29^{* * *} \\
(0.07)\end{array}$ & $\begin{array}{c}2.82^{* * *} \\
(0.78)\end{array}$ & $\begin{array}{c}2.01^{* * *} \\
(0.42)\end{array}$ & $\begin{array}{c}0.61^{* * *} \\
(0.13)\end{array}$ \\
\hline $\begin{array}{l}\text { Household head has } \\
\text { higher secondary education }\end{array}$ & $\begin{array}{c}0.32^{* * *} \\
(0.10)\end{array}$ & $\begin{array}{c}5.36^{* * *} \\
(1.23)\end{array}$ & $\begin{array}{c}2.66^{* * *} \\
(0.61)\end{array}$ & $\begin{array}{c}0.97^{* * *} \\
(0.18)\end{array}$ \\
\hline $\begin{array}{l}\text { Household head has } \\
\text { graduate degree }\end{array}$ & $\begin{array}{c}0.45^{* * *} \\
(0.17)\end{array}$ & $\begin{array}{c}8.60^{* * *} \\
(2.39)\end{array}$ & $\begin{array}{c}3.13^{* * *} \\
(1.11)\end{array}$ & $\begin{array}{c}1.22^{* * *} \\
(0.32)\end{array}$ \\
\hline $\begin{array}{l}\text { Household head has } \\
\text { other education }\end{array}$ & $\begin{array}{l}-0.66 \\
(0.64)\end{array}$ & $\begin{array}{l}-2.95 \\
(6.20)\end{array}$ & $\begin{array}{l}-1.41 \\
(2.60)\end{array}$ & $\begin{array}{l}-1.18 \\
(1.08)\end{array}$ \\
\hline $\begin{array}{l}\text { Spouse with primary } \\
\text { education }\end{array}$ & $\begin{array}{l}0.18^{* *} \\
(0.07)\end{array}$ & $\begin{array}{c}2.65^{* * *} \\
(0.83)\end{array}$ & $\begin{array}{l}1.27^{* * *} \\
(0.42)\end{array}$ & $\begin{array}{c}0.43^{* * *} \\
(0.14)\end{array}$ \\
\hline $\begin{array}{l}\text { Spouse with } \\
\text { secondary education }\end{array}$ & $\begin{array}{c}0.32^{* * *} \\
(0.07)\end{array}$ & $\begin{array}{l}4.33^{* * *} \\
(0.81)\end{array}$ & $\begin{array}{c}1.58^{* * *} \\
(0.40)\end{array}$ & $\begin{array}{c}0.59^{* * *} \\
(0.12)\end{array}$ \\
\hline $\begin{array}{l}\text { Spouse with higher } \\
\text { secondary education }\end{array}$ & $\begin{array}{c}0.45^{* * *} \\
(0.14)\end{array}$ & $\begin{array}{l}7.57^{* * *} \\
(1.68)\end{array}$ & $\begin{array}{l}1.73^{*} \\
(0.94)\end{array}$ & $\begin{array}{c}0.89^{* * *} \\
(0.27)\end{array}$ \\
\hline $\begin{array}{l}\text { Spouse with graduate } \\
\text { degree }\end{array}$ & $\begin{array}{c}0.01 \\
(0.98)\end{array}$ & $\begin{array}{c}8.11 \\
(9.11)\end{array}$ & $\begin{array}{c}0.22 \\
(3.90)\end{array}$ & $\begin{array}{c}0.99 \\
(1.69)\end{array}$ \\
\hline $\begin{array}{l}\text { Spouse with other } \\
\text { education }\end{array}$ & $\begin{array}{c}1.38^{* * *} \\
(0.49)\end{array}$ & $\begin{array}{l}-7.82 \\
(6.03)\end{array}$ & $\begin{array}{c}0.88 \\
(3.29)\end{array}$ & $\begin{array}{l}2.10^{*} \\
(1.10)\end{array}$ \\
\hline Lean Season & $\begin{array}{c}0.01 \\
(0.10)\end{array}$ & $\begin{array}{l}-1.17 \\
(1.07)\end{array}$ & $\begin{array}{c}0.38 \\
(0.69)\end{array}$ & $\begin{array}{c}0.26 \\
(0.22)\end{array}$ \\
\hline $\begin{array}{l}\text { Agricultural asset } \\
\text { per capita }(2010 \text { Tk.1,000) }\end{array}$ & $\begin{array}{c}0.01^{* * *} \\
(0.00)\end{array}$ & $\begin{array}{c}0.13^{* * *} \\
(0.03)\end{array}$ & $\begin{array}{c}0.07^{* * *} \\
(0.02)\end{array}$ & $\begin{array}{c}0.02^{* * *} \\
(0.00)\end{array}$ \\
\hline Constant & $\begin{array}{c}8.35^{* * *} \\
(0.27)\end{array}$ & $\begin{array}{c}47.57^{* * *} \\
(2.60)\end{array}$ & $\begin{array}{c}22.79^{* * *} \\
(1.32)\end{array}$ & $\begin{array}{c}7.10^{* * *} \\
(0.47)\end{array}$ \\
\hline Adjusted $\mathrm{R}^{2}$ & 0.219 & 0.233 & 0.253 & 0.254 \\
\hline $\mathrm{N}$ & 2,806 & 2,806 & 2,806 & 2,806 \\
\hline
\end{tabular}

Note: See footnotes in Table 3. 
TABLE A.3: Effect of the 2005-2010 rice price increase on Sellers' consumption by types of food categories

\begin{tabular}{|c|c|c|c|c|c|c|}
\hline & \multicolumn{6}{|c|}{ Calorie intake (Kcal. per capita per day) from } \\
\hline & $\begin{array}{c}\text { Grain } \\
(1)\end{array}$ & $\begin{array}{l}\text { Non rice } \\
\text { grain } \\
(2)\end{array}$ & $\begin{array}{c}\text { Pulses } \\
\text { (3) }\end{array}$ & $\begin{array}{c}\text { Protein } \\
\text { (4) }\end{array}$ & $\begin{array}{c}\text { Fruits } \\
\text { (5) }\end{array}$ & $\begin{array}{c}\text { Other } \\
\text { items } \\
(6)\end{array}$ \\
\hline Year 2010 & $\begin{array}{l}-44.69 \\
(28.45)\end{array}$ & $\begin{array}{c}94.35^{* * *} \\
(11.64)\end{array}$ & $\begin{array}{c}3.57 \\
(2.92)\end{array}$ & $\begin{array}{l}10.36^{*} \\
(5.70)\end{array}$ & $\begin{array}{c}17.64^{* *} \\
(7.45)\end{array}$ & $\begin{array}{c}30.02^{* * *} \\
(8.53)\end{array}$ \\
\hline Seller & $\begin{array}{c}99.92^{* * *} \\
(37.30)\end{array}$ & $\begin{array}{c}17.61 \\
(10.80)\end{array}$ & $\begin{array}{c}8.33^{* * *} \\
(3.19)\end{array}$ & $\begin{array}{c}39.92^{* * *} \\
(6.87)\end{array}$ & $\begin{array}{l}10.15 \\
(7.05)\end{array}$ & $\begin{array}{c}33.21^{* * *} \\
(10.33)\end{array}$ \\
\hline DD estimate & $\begin{array}{c}79.50 \\
(55.80)\end{array}$ & $\begin{array}{l}11.88 \\
(16.68)\end{array}$ & $\begin{array}{c}2.75 \\
(4.61)\end{array}$ & $\begin{array}{c}5.04 \\
(10.31)\end{array}$ & $\begin{array}{l}23.64^{* *} \\
(11.24)\end{array}$ & $\begin{array}{c}23.94 \\
(14.69)\end{array}$ \\
\hline Female head & $\begin{array}{l}-40.48 \\
(48.06)\end{array}$ & $\begin{array}{c}8.85 \\
(13.95)\end{array}$ & $\begin{array}{l}8.44^{* *} \\
(4.11)\end{array}$ & $\begin{array}{c}27.81^{* * *} \\
(8.58)\end{array}$ & $\begin{array}{c}44.67^{* * *} \\
(8.48)\end{array}$ & $\begin{array}{c}64.88^{* * *} \\
(11.44)\end{array}$ \\
\hline $\begin{array}{l}\text { Age of household } \\
\text { head }\end{array}$ & $\begin{array}{l}-0.64 \\
(1.03)\end{array}$ & $\begin{array}{c}0.51 \\
(0.32)\end{array}$ & $\begin{array}{c}0.08 \\
(0.08)\end{array}$ & $\begin{array}{c}0.15 \\
(0.18)\end{array}$ & $\begin{array}{l}-0.10 \\
(0.20)\end{array}$ & $\begin{array}{l}-0.22 \\
(0.25)\end{array}$ \\
\hline $\begin{array}{l}\text { Household head has } \\
\text { primary education }\end{array}$ & $\begin{array}{l}68.83^{*} \\
(36.48)\end{array}$ & $\begin{array}{l}20.74^{*} \\
(11.74)\end{array}$ & $\begin{array}{l}-1.98 \\
(2.74)\end{array}$ & $\begin{array}{c}17.24^{* * *} \\
(5.74)\end{array}$ & $\begin{array}{c}2.80 \\
(5.70)\end{array}$ & $\begin{array}{c}20.05^{* *} \\
(9.21)\end{array}$ \\
\hline $\begin{array}{l}\text { Household head has } \\
\text { secondary education }\end{array}$ & $\begin{array}{l}-23.42 \\
(31.02)\end{array}$ & $\begin{array}{c}9.21 \\
(9.44)\end{array}$ & $\begin{array}{l}1.50 \\
(2.26)\end{array}$ & $\begin{array}{c}15.62^{* * *} \\
(5.82)\end{array}$ & $\begin{array}{l}-3.79 \\
(5.06)\end{array}$ & $\begin{array}{c}17.34^{* *} \\
(8.10)\end{array}$ \\
\hline Household head has & -25.57 & $\begin{array}{l}17.10 \\
(1499)\end{array}$ & $\begin{array}{c}4.80 \\
(3.59)\end{array}$ & $32.41^{* * *}$ & $\begin{array}{l}12.27 \\
(10.93)\end{array}$ & $42.69^{* * *}$ \\
\hline higher secondary education & $\begin{array}{l}(50.68) \\
175 \cdot 1 * *\end{array}$ & $(14.99)$ & $(3.59)$ & $(10.85)$ & $(10.93)$ & $\begin{array}{c}(13.72) \\
5461^{* * *}\end{array}$ \\
\hline $\begin{array}{l}\text { Household head has } \\
\text { graduate degree }\end{array}$ & $\begin{array}{c}-175.84^{* *} \\
(79.64)\end{array}$ & $(19.78)$ & $\begin{array}{l}7.79 \\
(7.82)\end{array}$ & $\begin{array}{l}17.12 \\
(14.21)\end{array}$ & $\begin{array}{c}-50.17^{\text {*** }} \\
(14.12)\end{array}$ & $\begin{array}{l}54.01 \\
(20.95)\end{array}$ \\
\hline $\begin{array}{l}\text { Household head has } \\
\text { other education }\end{array}$ & $\begin{array}{c}94.40 \\
(180.69)\end{array}$ & $\begin{array}{l}-81.01 \\
(96.96)\end{array}$ & $\begin{array}{l}-7.55 \\
(13.37)\end{array}$ & $\begin{array}{l}-37.17^{*} \\
(20.45)\end{array}$ & $\begin{array}{c}-2.93 \\
(42.28)\end{array}$ & $\begin{array}{l}-55.02^{*} \\
(29.91)\end{array}$ \\
\hline $\begin{array}{l}\text { Spouse with primary } \\
\text { education }\end{array}$ & $\begin{array}{l}-62.53^{*} \\
(31.95)\end{array}$ & $\begin{array}{c}30.19^{* * *} \\
(10.87)\end{array}$ & $\begin{array}{l}-3.40 \\
(2.56)\end{array}$ & $\begin{array}{c}5.56 \\
(5.62)\end{array}$ & $\begin{array}{l}-7.04 \\
(5.26)\end{array}$ & $\begin{array}{l}12.90 \\
(7.89)\end{array}$ \\
\hline $\begin{array}{l}\text { Spouse with } \\
\text { secondary education }\end{array}$ & $\begin{array}{c}-115.72^{* * *} \\
(35.54)\end{array}$ & $\begin{array}{c}29.08^{* * *} \\
(10.45)\end{array}$ & $\begin{array}{c}0.70 \\
(2.50)\end{array}$ & $\begin{array}{c}14.48^{* *} \\
(6.68)\end{array}$ & $\begin{array}{l}11.48 \\
(8.11)\end{array}$ & $\begin{array}{c}20.28^{* *} \\
(9.00)\end{array}$ \\
\hline $\begin{array}{l}\text { Spouse with higher } \\
\text { secondary education }\end{array}$ & $\begin{array}{c}-206.28^{* * *} \\
(65.95)\end{array}$ & $\begin{array}{l}56.59^{* *} \\
(22.10)\end{array}$ & $\begin{array}{l}-6.10 \\
(5.54)\end{array}$ & $\begin{array}{c}13.53 \\
(12.98)\end{array}$ & $\begin{array}{l}-15.60 \\
(14.66)\end{array}$ & $\begin{array}{c}35.93^{*} \\
(18.70)\end{array}$ \\
\hline $\begin{array}{l}\text { Spouse with graduate } \\
\text { degree }\end{array}$ & $\begin{array}{l}-492.07 \\
(428.48)\end{array}$ & $\begin{array}{l}-60.16 \\
(46.44)\end{array}$ & $\begin{array}{l}-22.44^{*} \\
(12.85)\end{array}$ & $\begin{array}{l}-9.00 \\
(52.93)\end{array}$ & $\begin{array}{l}-46.81 \\
(42.09)\end{array}$ & $\begin{array}{c}-132.23^{* * *} \\
(28.18)\end{array}$ \\
\hline $\begin{array}{l}\text { Spouse with other } \\
\text { education }\end{array}$ & $\begin{array}{c}-72.79 \\
(149.11)\end{array}$ & $\begin{array}{c}524.50^{* * *} \\
(59.14)\end{array}$ & $\begin{array}{l}-10.87 \\
(8.36)\end{array}$ & $\begin{array}{l}28.69 \\
(33.37)\end{array}$ & $\begin{array}{c}-104.98^{* * *} \\
(27.39)\end{array}$ & $\begin{array}{c}114.14^{* *} \\
(47.14)\end{array}$ \\
\hline Lean Season & $\begin{array}{l}-57.50 \\
(36.35)\end{array}$ & $\begin{array}{l}-9.96 \\
(13.00)\end{array}$ & $\begin{array}{c}3.07 \\
(3.71)\end{array}$ & $\begin{array}{c}2.15 \\
(8.17)\end{array}$ & $\begin{array}{c}-37.32^{* * *} \\
(6.52)\end{array}$ & $\begin{array}{l}24.44^{*} \\
(12.89)\end{array}$ \\
\hline $\begin{array}{l}\text { Income per capita } \\
(2010 \text { Tk.1,000) }\end{array}$ & $\begin{array}{c}0.87 \\
(1.29)\end{array}$ & $\begin{array}{l}0.93^{* *} \\
(0.41)\end{array}$ & $\begin{array}{l}0.19^{*} \\
(0.10)\end{array}$ & $\begin{array}{l}0.94^{* *} \\
(0.44)\end{array}$ & $\begin{array}{c}0.25 \\
(0.27)\end{array}$ & $\begin{array}{l}0.78 \\
(0.48)\end{array}$ \\
\hline $\begin{array}{l}\text { Agricultural asset } \\
\text { per capita }(2010 \text { Tk.1,000) }\end{array}$ & $\begin{array}{l}3.76^{* *} \\
(1.59)\end{array}$ & $\begin{array}{c}0.31 \\
(0.43)\end{array}$ & $\begin{array}{l}0.22^{* *} \\
(0.10)\end{array}$ & $\begin{array}{c}1.08^{* * *} \\
(0.26)\end{array}$ & $\begin{array}{c}0.97^{* * *} \\
(0.37)\end{array}$ & $\begin{array}{c}1.00^{* * *} \\
(0.27)\end{array}$ \\
\hline Constant & $\begin{array}{c}1935.64^{* * *} \\
(128.88)\end{array}$ & $\begin{array}{c}-7.32 \\
(35.09)\end{array}$ & $\begin{array}{c}32.75^{* * *} \\
(10.34)\end{array}$ & $\begin{array}{c}110.25^{* * *} \\
(27.47)\end{array}$ & $\begin{array}{c}249.48^{* * *} \\
(24.87)\end{array}$ & $\begin{array}{c}210.75^{* * *} \\
(32.83)\end{array}$ \\
\hline Adjusted $\mathrm{R}^{2}$ & 0.204 & 0.268 & 0.254 & 0.225 & 0.266 & 0.287 \\
\hline $\mathrm{N}$ & 2,806 & 2,806 & 2,806 & 2,806 & 2,806 & 2,806 \\
\hline
\end{tabular}

Note: See footnotes in Table 3. 
TABLE A.4: Effect of the 2005-2010 rice price increase on the Sellers' consumption of high and low value items

\begin{tabular}{lcccc}
\hline & \multicolumn{4}{c}{ Calorie intake (Kcal. per capita per day) from } \\
\cline { 2 - 5 } & High value pulses & Low value pulses & High value fish & Low value fish \\
& $(1)$ & $(2)$ & $(3)$ & $(4)$ \\
\hline Year 2010 & 1.45 & 2.11 & -1.87 & $10.01^{* * *}$ \\
& $(2.28)$ & $(1.73)$ & $(1.59)$ & $(1.87)$ \\
Seller & $7.80^{* * *}$ & 0.52 & $5.29^{* *}$ & $8.90^{* * *}$ \\
& $(2.64)$ & $(1.61)$ & $(2.12)$ & $(1.81)$ \\
DD estimate & 3.95 & -1.20 & -0.09 & -1.19 \\
& $(3.89)$ & $(2.24)$ & $(3.05)$ & $(2.83)$ \\
Constant & $15.05^{* *}$ & $17.70^{* *}$ & $36.04^{* * *}$ & $25.86^{* * *}$ \\
& $(7.59)$ & $(6.95)$ & $(6.72)$ & $(7.17)$ \\
Adjusted $\mathrm{R}^{2}$ & 0.308 & 0.176 & & 0.294 \\
$\mathrm{~N}$ & 2,806 & 2,806 & 2,806 & 2.806 \\
\hline
\end{tabular}

Note: See footnotes in Table 3.

TABLE A.5: Effect of the 2005-2010 rice price increase on Sellers' consumption

\begin{tabular}{lccc}
\hline & \multicolumn{3}{c}{ Log of per capita consumption value of } \\
\cline { 2 - 4 } & $\begin{array}{c}\text { Rice } \\
(1)\end{array}$ & $\begin{array}{c}\text { Non rice food items } \\
(2)\end{array}$ & $\begin{array}{c}\text { Non food items } \\
(3)\end{array}$ \\
\hline Year 2010 & $0.57^{* * *}$ & $0.67^{* * *}$ & $0.57^{* * *}$ \\
& $(0.02)$ & $(0.04)$ & $(0.05)$ \\
Seller & -0.00 & $0.16^{* * *}$ & $0.23^{* * *}$ \\
& $(0.02)$ & $(0.04)$ & $(0.05)$ \\
DD estimate & $0.09^{* * *}$ & 0.01 & -0.04 \\
& $(0.03)$ & $(0.05)$ & $(0.07)$ \\
Log(income per & 0.00 & $0.12^{* * *}$ & $0.19^{* * *}$ \\
capita) & $(0.01)$ & $(0.01)$ & $(0.02)$ \\
Constant & $5.50^{* * *}$ & $4.76^{* * *}$ & $4.01^{* * *}$ \\
& $(0.12)$ & $(0.19)$ & $(0.23)$ \\
Adjusted $\mathrm{R}^{2}$ & & & \\
$\mathrm{~N}$ & 0.571 & 0.645 & 0.535 \\
& 1,563 & 1,563 & 1,563 \\
\hline
\end{tabular}

Note: See footnotes in Table 3. 


\section{Notes}

${ }^{1}$ The domestic price increase during 2005-2010 for typical non rice food items and non food items were relatively low compared to the increase in the prices of rice (Hasan, 2016b).

${ }^{2}$ The reason for dropping urban households from the analysis is that food price risk differs between rural and urban areas (Barrett, 1996).

${ }^{3}$ Agricultural production was found to serve as a hedge against higher food prices during 2004-2008 in Bangladesh (Balagtas et al., 2014). The effect of higher food prices on child labour and school enrolment were also found to differ with households access to agricultural lands (Hou et al., 2016).

${ }^{4}$ Landholding is also adjusted for the average cropping intensity by districts. For detail, see Hasan (2016b).

${ }^{5}$ Food items and food groups have also been used in earlier research on food security/dietary diversity (for example, Wiesmann et al., 2009).

${ }^{6}$ The mean rice price in July 2005 and July 2010, the two points in time at which the survey data were collected, was Tk.15.57 and Tk.27.85, respectively. This change was caused by the higher international food price in 2007-08 and major changes in the exchange rate in 2010 (Hasan, 2016b).

${ }^{7}$ While all tests are conducted at the $5 \%$ level, following the recommendation of American Statistical Association that emphasizes focusing less of p-values but more on full reporting and transparency, we retained all the insignificant variables in our models (Wasserstein and Lazar, 2016).

${ }^{8}$ All results are available from the author upon request.

${ }^{9}$ High value pulses include Lentil, Chickling vetch and Green Gram while low value pulses include Pea Gram, Mashkalai and other types of pulses. Among fishes, we consider Hilsa, Magur, Shinghi, Khalisha, Koi, Shoal, Gajar, Taki, Mala, Kachki, Chala, Chapila, Batashi, Shrimp, Tangra, Eelfish, Baila, Tapashi and other fishes as high value while Rhui, Katla, Mrigel, Kalbaush, Pangash, Boal, Air, Silver Carp, Grass Carp, Miror Carp, Puti, Big Puti, Telapia, Nilotica and saltwater fishes are considered as low value.

${ }^{10}$ See Appendix, Table A.1-A.5, for main results with sellers. 


\section{REFERENCES}

Akter, S. and Basher, S. A. (2014). The impacts of food price and income shocks on household food security and economic well-being: Evidence from rural Bangladesh. Global Environmental Change, 25:150-162.

Alem, Y. and Söderbom, M. (2012). Household-level consumption in urban Ethiopia: The effects of a large food price shock. World Development, 40(1):146-162.

Balagtas, J. V., Bhandari, H., Cabrera, E. R., Mohanty, S., and Hossain, M. (2014). Did the commodity price spike increase rural poverty? Evidence from a long-run panel in Bangladesh. Agricultural Economics, 45(3):303-312.

Barrett, C. B. (1996). Urban bias in price risk: The geography of food price distributions in lowincome economies. The Journal of Development Studies, 32(6):830-849.

BBS (2007). Report of the Household Income and Expenditure Survey 2005. Report, Bangladesh Bureau of Statistics, Ministry of Planning, Government of the People's Republic of Bangladesh.

BBS (2012). Report of the Household Income and Expenditure Survey 2010. Report, Bangladesh Bureau of Statistics, Ministry of Planning, Government of the People's Republic of Bangladesh.

Becker, G. S. (1965). A theory of the allocation of time. Economic Journal, 75(299):493-517.

Bertrand, M., Duflo, E., and Mullainathan, S. (2004). How much should we trust differences-indifferences estimates? Quarterly Journal of Economics, 119(1):249-275.

Brinkman, H.-J., de Pee, S., Sanogo, I., Subran, L., and Bloem, M. W. (2010). High food prices and the global financial crisis have reduced access to nutritious food and worsened nutritional status and health. Journal of Nutrition, 140(1):153S-161S.

D'Souza, A. and Jolliffe, D. (2012). Rising food prices and coping strategies: Household-level evidence from Afghanistan. Journal of Development Studies, 48(2):282-299.

D'Souza, A. and Jolliffe, D. (2014). Food insecurity in vulnerable populations: Coping with food price shocks in Afghanistan. American Journal of Agricultural Economics, 96(3):790-812. 
Fitzsimons, E., Malde, B., Mesnard, A., and Vera-Hernández, M. (2016). Nutrition, information and household behavior: Experimental evidence from Malawi. Journal of Development Economics, 122:113-126.

Griffith, R., O'Connell, M., and Smith, K. (2016). Shopping around: How households adjusted food spending over the great recession. Economica, 83(330):247-280.

Hasan, S. A. (2016a). Engel curves and equivalence scales for Bangladesh. Journal of the Asia Pacific Economy, 21(2):301-315.

Hasan, S. A. (2016b). The impact of the 2005-10 rice price increase on consumption in rural Bangladesh. Agricultural Economics, 47(4):423-433.

Hasan, S. A. (2017). The distributional effect of a large rice price increase on welfare and poverty in Bangladesh. Australian Journal of Agricultural and Resource Economics, 61(1):154-171.

Hou, X., Hong, S. Y., and Scott, K. (2016). The heterogeneous effects of a food price crisis on child school enrolment and labour: Evidence from Pakistan. The Journal of Development Studies, $52(5): 718-734$.

Ivanic, M. and Martin, W. (2008). Implications of higher global food prices for poverty in lowincome countries. Agricultural Economics, 39(s1):405-416.

Jones, A. D., Ngure, F. M., Pelto, G., and Young, S. L. (2013). What are we assessing when we measure food security? A compendium and review of current metrics. Advances in Nutrition, $4(5): 481-505$.

Jones, A. D., Shrinivas, A., and Bezner-Kerr, R. (2014). Farm production diversity is associated with greater household dietary diversity in Malawi: Findings from nationally representative data. Food Policy, 46:1-12.

Kaplan, G. and Menzio, G. (2015). The morphology of price dispersion. International Economic Review, 56(4):1165-1206. 
Kennedy, G. L., Pedro, M. R., Seghieri, C., Nantel, G., and Brouwer, I. (2007). Dietary diversity score is a useful indicator of micronutrient intake in non-breast-feeding Filipino children. Journal of Nutrition, 137(2):472-477.

Kumar, N. and Quisumbing, A. R. (2013). Gendered impacts of the 2007-2008 food price crisis: Evidence using panel data from rural Ethiopia. Food Policy, 38:11-22.

MoFDM (2006). Food Policy. Policy document, Ministry of Food and Disaster Management, Government of the People's Republic of Bangladesh.

Muralidharan, K., Niehaus, P., and Sukhtankar, S. (2016). Building state capacity: Evidence from biometric smartcards in India. American Economic Review, 106(10):2895-2929.

Nevo, A. and Wong, A. (2015). The elasticity of substitution between time and market goods: Evidence from the Great Recession. Working Paper - 21318, NBER, Cambridge, MA.

Planning Commission (2015). Seventh Five Year Plan, FY2016-FY2020. Plan document, Ministry of Planning, Government of the People's Republic of Bangladesh.

Raihan, S. (2009). Impact of food price rise on school enrollment and dropout in the poor and vulnerable households in selected areas of Bangladesh. Report, UK Department for International Development, Dhaka.

Schmidt, L., Shore-Sheppard, L., and Watson, T. (2017). The effect of safety net programs on food insecurity. Journal of Human Resources. forthcoming.

Steyn, N., Nel, J., Nantel, G., Kennedy, G., and Labadarios, D. (2006). Food variety and dietary diversity scores in children: Are they good indicators of dietary adequacy? Public Health Nutrition, 9(05):644-650.

Sulaiman, M., Parveen, M., and Das, N. C. (2009). Impact of the food price hike on nutritional status of women and children. Monograph 38, Research and Evaluation Division, BRAC, Dhaka.

Swindale, A. and Bilinsky, P. (2006). Household dietary diversity score (HDDS) for measurement of household food access: Indicator guide. Food and Nutrition Technical Assistance Project, Academy for Educational Development. 
Torlesse, H., Kiess, L., and Bloem, M. W. (2003). Association of household rice expenditure with child nutritional status indicates a role for macroeconomic food policy in combating malnutrition. Journal of Nutrition, 133(5):1320-1325.

Wasserstein, R. L. and Lazar, N. A. (2016). The ASA's statement on p-values: Context, process, and purpose. American Statistician, 70(2):129-133.

West, K. P. and Mehra, S. (2010). Vitamin A intake and status in populations facing economic stress. Journal of Nutrition, 140(1):201S-207S.

Wiesmann, D., Bassett, L., Benson, T., and Hoddinott, J. (2009). Validation of the world food programme's food consumption score and alternative indicators of household food security. Discussion Paper-00870, IFPRI, Washington DC.

World Food Programme (2008). Food consumption analysis: Calculation and use of the food consumption score in food security analysis. Report, Vulnerability Analysis and Mapping Branch, WFP, Rome. 